\title{
The Relative Indicators to Agriculture Policy Development Paradigms: Local Restraints, Global Trends*
}

\author{
Shamsuddin Ahmed \\ York University, Toronto, Canada
}

\begin{abstract}
Recent trends in agriculture and rural development divulge apparently untidy land governance that performs a narrower livelihood from the agriculture value in the domestic product. This situation continues as a result of summative population density, prolific industrial augmentation, and the huge urban settings that compel the varied land transits and community services. Antagonistically, countries apart from regional economic influences rather have extricated development assistance that is based on national income capability of a country which accumulates the gross domestic product (GDP) impulsively with agricultural stagnation. Data from 1991 to 2011 of 140-206 countries expose a substantial decline in agriculture value in GDP. Local land coverage data indicate rapid changes of agriculture lands to settlements, growth centers, urban corridors, or the commercial areas. At this point, this paper tried to explore the relative indicators to agriculture policy development paradigms in the global context in viewing the current constraints at the local level.
\end{abstract}

Keywords: agriculture value, development assistance, labour dynamics, paradigms, trends

Recent trends in agriculture and rural development divulge apparently untidy land governance that performs a narrower livelihood from the agriculture value in the domestic product. Antagonistically, countries apart from regional economic influences rather have national income capability that depends on extricated development assistance which accumulates the gross domestic product (GDP) impulsively with agricultural stagnation. Policy-innovative new programs in agricultural machinery had twisted development contemplations with socio-economic boundaries and agro-ecological structures. Nevertheless, trends in agriculture policy shape rather an imperceptible shifting of rural livelihoods competing to urban intensification, commercial corridors development, and rural labour migrations. Data from 1991 to 2011 of world countries 140-206 expose a substantial decline in agriculture value added in GDP.

GDP has become a narrower dependency with the agriculture lands, rural population, labour dynamics, and the food-crops-livestock product indexes. The allocation of the development assistances — while succeeding the attempts for poverty alleviation - targets the regional economic improvement with other sectors like

\footnotetext{
* This paper had been accepted for and presented at the 2016 World Bank Conference on Land and Poverty, the World Bank, Washington D.C., March 14-18, 2016. The paper is an individual research and does not necessarily represent the views of others or the institutions where the author is affiliated or associated.

Corresponding author: Shamsuddin Ahmed, M.S. (environmental science), MPA (governance and public policy), MPPAL (public policy, administration and law), Graduate Diploma in Justice System Administration, Certificate in Applied Digital Geogarphy and GIS, regular member of the Institute of Public Administration of Canada and research associate of York Centre for Public Policy and Law, York University, Canada; research fields: environmental science, public affairs, public policy, public administration, and geographic information systems and remote sensing data analytics.
} 
infrastructures improving the accesses to electrifications, water and sanitations, and roads and highways. Agriculture lands experience a continuing decay to the adequate cereal crops and long-term agriculture productivity. This situation occurs as a result of imbalance among rain-fed water domains, smaller farming size, declined rural labours, changes in topographic floodplain contours, asymmetrical spatial or temporal inundation land types, and the lessened topsoil quality because of the earthworks for new public infrastructures and assets development. These factors dispute the agriculture land consolidations for homogeneous crops cultivation adjoining to the smaller farming lots with technological implications of large-scale agrarian development.

Public expenditures and the rural cooperatives adopt the means of productivity in agriculture farming to support the rationalized food crops production. Examples are canal irrigation plans, deep tube-well irrigation management programs, surface water drainage regulators, and the low-lying agriculture land with a closed dam, especially in a coastal embankments scheme. This system bore the evidence of the decades as witnessed from the country experience in farming policy implications. Conceivably, most of those structures now in the low and middle-income countries are dysfunctional or rarely operated chiefly because of agriculture stagnation and flaw in institutional maintenance. Agricultural technological improvement is necessary to recover irrigation, flood control, and water drainage rehabilitation with environmental extenuation to maintain the quality of optimum surface water and unlock the potentials of groundwater. At this point, this paper tried to explore the relative indicators to agriculture policy development paradigms in a global context in viewing the spatial and temporal constraints at the local level.

Agriculture land structure ought to be a crucial integration in land governance with an emphasis of monitoring the current land use impact to develop a policy model for sustainable land management at least with two key considerations. Firstly, the dominant land use variables such as agriculture tenancy, housing, settlements, vegetation, and water bodies. Secondly, the relative complex factors namely community and ecology, and policy and institution. Land use zoning characterization imposes the land governance policy issues in agriculture and rural development, such as proper land use, poverty reduction, local dispute resolution, physical planning, and public assets management initiatives. This research assembles the findings in conjunction with global situation and the local impediments in the agricultural structures. The organization of the paper includes five sections. The following section describes data and methodology (Section 2). Section 3 reviews the insights on agriculture policy development paradigms while Section 4 is a critical analysis of the relative indicators to agriculture development patterns, and envisaging a possible practice to delineate a mandatory portion of agriculture lands. Section 5 concludes the paper.

\section{Data and Methodology}

This paper cautiously incorporates the review of the literature, knowledge from procedural innovation for land use data gathering, and the World Bank's data that are publicly available. Analyses of data comprise the following steps: (1) review of World Bank's records of 140-206 countries from 1991 to 2011 ${ }^{1}$. The relational data tuples of the countries were categorized by income group and by region while "country name" is the referential key attribute; (2) identification of variables associated with agriculture lands, labour dynamics, financial assistance, and the agriculture production indexes; (3) understanding the comparative trends in development assistance versus agriculture value to GDP and the variables associated in the global context by region and income group; (4) analysis of historical data by region, income groups, and the local level trends in

\footnotetext{
${ }^{1}$ Accessed in 2015 from http://data.worldbank.org/indicator that follows data organization into a single database and statistical analyses.
} 
agriculture; (5) review of land covers classifications by agriculture, settlements, and wetlands habitats to recognize the land use change dynamics over a decade at the local level; and (6) a development policy paradigm for an informed agriculture lands occupancy.

Data analyses encompass categorical classifications from the World Bank data by regions, and by income group where high-income countries are identified and integrated here as non-OECD (Organization for Economic Co-operation and Development) and OECD groups for data analysis. A summary matrix showing the effects of ODA (Official Development Assistance) by income group can be seen in Figure 1. Provisional data variables are analyzed to assess the relationships among the indicators pertinent to agriculture and rural development components (see Figure A-1 to Figure A-6 in Appendix A). The following data variables provide an intuition for recognizing the trends in the agricultural sector lands and rural occupancies (for explanation of variables see http://data.worldbank.org/indicators):

(1) Agriculture land areas of total lands, percent (\%);

(2) Proportion of rural populations, percent (\%);

(3) Agriculture value added in GDP, percent (\%);

(4) Crops production index, percent (\%);

(5) Food production index, percent (\%);

(6) Active labour population (aged 15-64), percent (\%);

(7) GDP per capita, US\$;

(8) Net or ODA, US\$;

(9) $\mathrm{CO}_{2}$ emissions per capita, metric tonnes (m.t.);

(10) Local level variables in agriculture and rural occupancies, especially in a country, are predominantly the land use change dynamics separable by:

(a) Agriculture labour population (\%);

(b) Households labour population (\%);

(c) Change in settlements, including homestead vegetation coverage (\%);

(d) Change in agriculture lands (\%);

(e) Change in permanent water bodies (\%).

\section{Understanding Agriculture Policy Development Paradigms}

The historical data distinguish some key variables to be critical for scaling responsible land governance to the agrarian structure. High-income nations - as the hugely successful economies countries apply physical tools in land administration to appraise and convey the policy-initiative new innovative programs for reasonable, sensible, and secure land tenure with attractive development and clear land taxation plans-are not much optimistic about the food crops production and the mutual tariff and trades in agriculture. Inescapably, agriculture policy in developed nations needs to be allowed for rural population's ability to work in the land despite the fact that the urban zone alters the agriculture land areas for development purpose. The diminishing proportion of both the rural population and the agriculture lands in a country, as a result of urban growth, affects agriculture value in GDP share while there continuing effects of ODA are sensible in the global economies. In this aspect, this section travels to synchronize the notions of agriculture policy development standards in three aspects: (1) the agriculture policy in development goals; (2) the agriculture households and rural population; and (3) the agriculture growth and crops productivity. 


\section{Agriculture Policy and the Development Goals}

The symmetry of regional or provincial planning policy in agriculture and rural development conflicts the local land use for food crops production because of the mounting number of the municipal agencies and the non-agricultural activities in the suburbs. Goals in the agricultural sector development policy undoubtedly refer the Millennium Development Goals (MDGs) toward the Sustainable Development Goals (SDGs) as the recent challenges to an understanding of "transformative paradigm"-which is patently applicable in valuing the global policy trends concerning the regional and local vulnerability in food crops production. The member states of the United Nations adopted the MDGs with eight declarations in 2000 while the relation of MDGs with agriculture and rural development focuses $70 \%$ target groups of the population mostly in Asia and Africa (The World Bank, 2006). Agriculture and rural components in these regions are said to be critical. MDGs' declaration No. 1-“eradicate extreme poverty and hunger" would be enforced to establish the declaration No. 8 - “... a global partnership for development" assumed to be directly sustainable inputs for the agriculture food production. Moreover, Sustainable Development Agenda 21 systematically enumerated Chapter 14-"promoting sustainable agriculture and rural development" on national and global development agriculture policy and Chapter 32- "strengthening the role of farmers" emphasizing the local farmers and rural households (United Nations, 1992).

Nonetheless, the complementary requirements concerning the agriculture production are impenetrable to the successful implications of the declared development goals at the households' level. For example, "the equitable distribution of farm land across the population" would merely apply to the particular country other than the geographic region or the income group. On the contrary, "access to agriculture productions and markets to regional and global trades" imposed on the global political economy is principally stirred in the international development assistance that is globally wrought by IMF (International Monetary Fund) and the World Bank. Global policy and the regional cooperation in terms of sustainability also aim to eliminate deficiency provoked from ideological and cultural metamorphosis. Ideologically, the axiological assumption of "transformative paradigm" relies on four fundamental principles (Martens \& Wilson, 2012, p. 164): "the importance of being culturally respectful", "the promotion of social justice", "the furtherance of human rights", and "addressing inquiries". These moralities should ground sustainable agriculture and food production network under the regional cooperation and the global policy context. Issues of greenhouse gas (GHG) emissions also need substantive attentions in environmental policy to sustain the country level development in transportation and industry sectors (Ahmed, 2015), notwithstanding consistent to the agro-industries and livestock. Yearly aggregate emissions of $\mathrm{CO}_{2}$ gas in OECD countries in North America were 15.6 m.t. per capita while the non-OECD countries in the Middle-East region showed 22.1 m.t. (see Appendix A: Figure A-1 and Figure A-2). With time, the SDGs vision fragmented in 17 goals is rather the reformist replacement that has to be practically operative to the countries' agriculture households and rural occupancies by the lessons learned from the inference of MDGs. One of which is for assuring the "means" of local food security with the regional and global partnership that would ideally focus on rural populations involved in the agriculture households' workers. Largely, SDGs' goals and targets readdressing the "systematic issues" for "policy and institutional coherence" (United Nations, 2016, p. 39) ought to be imperative for a country to ensure its GDP portion ensuring the agriculture policy standards toward the permissible agriculture lands and crops production.

\section{Agriculture Households and Rural Population}

Agriculture households and crops productivity indeed in any country are potentially risky because of the 
emerging economic growth forceful from non-agriculture sectors. Agriculture households represent the proportion of rural population allied with agriculture tenures to a relative contribution to GDP. According to the "Malthusian Population Trap" (Todaro, 2000, p. 224; Kogel \& Prskawetz, 2000), the divergence and elasticity between income growth and agriculture productivity postulate demographic transition situations that affect agriculture and rural development, especially in a third world country. The prognostic revelation appeared in this belief is threefold. Firstly, unavoidably a very low level per capita income exists with a consistent population growth. Secondly, in an aggregate income level and total population: faster growing of total population than that of aggregate income will reduce per capita income of a country - while aggregate income as the total product is rising faster, subsequently per capita income must be increasing. Finally, industrializations must require increasing growth in overall productivity factors in the agriculture sector preventing from agriculture stagnation and to raise the living standards and the dwelling values of the rural people. However, these ideological clarifications have varied outcome firmly in the income group countries and to the regional influences on land holdings and domestic products in a locality.

Willamson, Enemark, Wallace, and Rajabifard (2010, p. 189) reviewed the primary constraints in land consolidation to elucidate the plausible mechanisms in the land administration that would be relevant to adapting the structure of agriculture holdings in rural areas to optimize the circumference of agriculture productions. Magdoff (2007) reported that the quality of soils and crops cultivation is relatively snagging by agriculture subsidies, markets and prices as a result of imbalance tariff and trades of foods. It ultimately disregards the relevance of ecological agriculture that is in effect principally by economics, government policy, and the consumers' demands at the country level. The usual practices of agriculture businesses affect local crops cultivations, including production level and local food security especially the subsistence farmers in the least developed, low-income, or underdeveloped countries. In magnitude, labour flux migrates to the urban areas where the number of slum dwellers increasingly exposed to the urban workforce. The world's labour populations are industrious largely in the crops cultivations, food industries, and other service sectors. In 2011, the United Nations (UN) estimated the global population seven billion approximately that is divisible by dwelling in three-state residents - rural, urban, and slum dwellers-while the ratio of rural population, urban population, and the slum dwellers is 3:2:1. Clearly, the constancy of rural populations and dwellings is influenced by the circumference of agriculture growth and crops productivity.

\section{Agriculture Growth and Crops Productivity}

Trends in agriculture and crops productivity upset the successive growth. Changes in agriculture stagnation and subsequent rural transformation deviate at least in three parameters: percentage of rural population, percent of labour force in agriculture, and the portion of agriculture value in GDP. Higher production in smaller size land holdings with a linear growth of agriculture production, area and productivity apparently shows stagnation in food grains, non-food grains, and all crops. Agricultural growth (Rao, 1965, pp. 407-412; Todaro, 2000, p. 365) controls agriculture and food productions and subsequently bids leanings in policy implication. Rao argued that agriculture stagnation occurred because of inefficient or little use of technology regardless of the production area could be overcome by improving irrigation facilities despite the large farms often face obstacles in labour input costs.

Crops productivity that affects a country's food crops production indeed depends on ecological order and land suitability as the limiting factors such as quality of soils and water, availability of water, pests and 
pathogens, and local crops varieties (Sachs, 2008, p. 213; Botkin \& Keller, 2005, p. 204). Irrigated agriculture lands prevailing mostly with smaller farms are inadequate because of drought prone or lack of river-based irrigation. While Africa and Sub-Sahara region is an instance of this situation, South Asia remained the superior practice of agriculture production under the irrigated lands till a decade ago. Change in crops productivity commonly occurs because of inadequate or excessive rainfalls and increased air pollution that results from a massive decline in crops yield at the local level. Sachs' opinion moreover denoted that low agriculture productivity, among other things, such as poor coverage of public services and infrastructure and a few spots characterizes "subsistence economy" where many countries are trapped in poverty while other countries are in economic development.

This circumference remains mostly in the low-income group or least developed countries. Irrigation facilities had been retained for a particular period to some extent merely a couple of decades at last befitted deprived. The apparent reasons were:

(1) Diffusions of rural population growth are extremely high and outwardly transformed to the participating urban labour forces including the youth population;

(2) Changes in inundation land types or floodplain topography because of the expansion of urban fringes, new settlements, and flood frequencies;

(3) Lack of ideal availability of long-term irrigation sourcing the groundwater and surface water contents.

\section{The Relative Indicators to Agriculture Policy Development: An Analysis}

An implication of agriculture policy development is also fundamentally associated with modernization of agronomy. Modernization includes seed varieties, chemical fertilizer, modern irrigation, and new policy initiatives on the topographical conditions such as weather and climate suitability which are inevitable to explore local and regional effectiveness in agriculture crops and food production and its value added in GDP. Canada and other winter-prone spheres among the high-income countries are yet streaky from yearly cereal crops production due to the topographical and ecological conditions that yield an elongated stagnation in agriculture growth at the end. According to the Agriculture and Agri-Food Canada (2015), agriculture crops yields in Canada are also at risk with climate change impact, and this situation is disconcerting and may cause devastation from the unexpected occurrence of droughts in 2011/2002 and violent storms in 2010/2011.

Table 1

Number of Countries (C) as the Data Samples by Region and Income Group

\begin{tabular}{|c|c|c|c|c|c|c|c|c|c|c|c|c|}
\hline \multirow{2}{*}{$\frac{\text { Income group }}{\text { Region }}$} & \multicolumn{2}{|c|}{ Low income } & \multicolumn{2}{|c|}{$\begin{array}{c}\text { Lower middle } \\
\text { income }\end{array}$} & \multicolumn{2}{|c|}{$\begin{array}{l}\text { Upper middle } \\
\text { income }\end{array}$} & \multicolumn{2}{|c|}{$\begin{array}{l}\text { High income- } \\
\text { non-OECD }\end{array}$} & \multicolumn{2}{|c|}{$\begin{array}{c}\text { High income-- } \\
\text { OECD }\end{array}$} & \multicolumn{2}{|c|}{$\begin{array}{c}\text { Total world } \\
\text { countries }\end{array}$} \\
\hline & $\mathrm{C}$ & $\%$ & $\mathrm{C}$ & $\%$ & $\mathrm{C}$ & $\%$ & $\mathrm{C}$ & $\%$ & $\mathrm{C}$ & $\%$ & $\mathrm{C}$ & $\%$ \\
\hline East Asia \& Pacific & 2 & 6.5 & 12 & 23.5 & 10 & 18.9 & 9 & 18.8 & 4 & 12.5 & 37 & 17.2 \\
\hline Europe \& Central Asia & - & - & 8 & 15.7 & 12 & 22.6 & 13 & 27.1 & 24 & 75.0 & 57 & 26.5 \\
\hline Latin America \& Caribbean & 1 & 3.2 & 6 & 11.8 & 17 & 32.1 & 16 & 33.3 & 1 & 3.1 & 41 & 19.1 \\
\hline Middle East \& North Africa & - & - & 6 & 11.8 & 7 & 13.2 & 7 & 14.6 & 1 & 3.1 & 21 & 9.8 \\
\hline North America & - & - & - & - & - & - & 1 & 2.1 & 2 & 6.3 & 3 & 1.4 \\
\hline South Asia & 2 & 6.5 & 5 & 9.8 & 1 & 1.9 & - & - & - & - & 8 & 3.7 \\
\hline Sub-Sahara Africa & 26 & 83.9 & 14 & 27.5 & 6 & 11.3 & 2 & 4.2 & - & - & 48 & 22.3 \\
\hline Total world countries & 31 & 14.4 & 51 & 23.7 & 53 & 24.7 & 48 & 22.3 & 32 & 14.9 & 215 & 100.0 \\
\hline
\end{tabular}

Note. Source of data is the World Bank (2015), retrieved for the years from 1991 to 2011 (http://data.worldbank.org/indicator). 
Table 1 is the distribution of the frequencies of countries that indicate the data samples for research examination. Regionally, the Europe and Central Asia represent higher samples as 57 countries (26.5\%) followed by Sub-Saharan Africa that have 48 countries (22.3\%). By income group, the upper middle-income countries have higher representation (24.7\%) followed by lower middle-income countries $(23.7 \%)$-while low-income countries represented $14.4 \%$. This section illustrates the results in four issues: (1) the ODA and local labour dynamics in agriculture; (2) the trends in agriculture lands, yields, and values: global, regional and income group countries; (3) a country-level instance in agriculture and rural occupancies constraints; and (4) an innovative method in data gathering and agriculture lands delineation.

\section{ODA and Local Labour Dynamics in Agriculture}

Table 2 is a summary matrix of the undulating effects of net or ODA with the relative indicators to agriculture and rural development. Factors among the other issues associated such as the development of urban compounds are dominant to the agriculture land transition - if we see the correlations of variables (see Figure A-3). The World Bank Group is increasingly shifting its development financial assistance to the African countries $(61 \%)$ and categorically in the low-income group countries (123\%) in 2011 than that of 1991 (see Table 3). Trends in labour force population aged between 15 and 64 with ODA reflect a varying pattern in agriculture policy effect in a global context and by income group countries since 1991. This change in due course influences new infrastructures in rural sectors with the accessibility of improved dwelling facilities such as safe water, public sanitation, and electricity access to the populations.

Table 2

Undulating Effects of Net or ODA With the Relative Indicators to Agriculture and Rural Development: Countries in the Different Income Group and World-Wide, 2011

\begin{tabular}{|c|c|c|c|c|c|c|}
\hline Variables/Factors & Low income & $\begin{array}{l}\text { Lower } \\
\text { middle } \\
\text { income }\end{array}$ & $\begin{array}{l}\text { Upper } \\
\text { middle } \\
\text { income }\end{array}$ & $\begin{array}{l}\text { High income } \\
\text {-Non-OECD }\end{array}$ & $\begin{array}{l}\text { High income } \\
\text { - OECD }\end{array}$ & $\begin{array}{l}\text { All world } \\
\text { countries }\end{array}$ \\
\hline Total population & + High & + Low & -V. Low & + V. High & $\mathrm{N} / \mathrm{A}$ & + Low \\
\hline Rural population & + High & +Low & -V. Low & + V. High & $\mathrm{N} / \mathrm{A}$ & + Low \\
\hline Rural population (\%) & + Low & + V. Low & -Low & -High & N/A & + High \\
\hline Labour force population & + High & + Low & -V. Low & +V. High & N/A & + V. Low \\
\hline Labour force $(\%)$ & -Low & No & -Low & -High & N/A & - V. Low \\
\hline Agriculture GDP (\%) & -Low & + Low & $-V$. Low & + Low & $\mathrm{N} / \mathrm{A}$ & + V. Low \\
\hline GDP per capita & -Low & -Low & + V. Low & $-V$. Low & N/A & - Low \\
\hline GNI (Gross National Income) per capita & -Low & -Low & + V. Low & + V. Low & $\mathrm{N} / \mathrm{A}$ & - V. Low \\
\hline Arable lands of total land (\%) & - V. Low & + Low & $+V$. Low & + V. Low & N/A & + Low \\
\hline Arable land per capita & $-V$. Low & No & $+V$. Low & +V. High & $\mathrm{N} / \mathrm{A}$ & No \\
\hline Improved water access population (\%) & -Moderate & + V. Low & $-V$. Low & + Low & N/A & - Low \\
\hline Fertilizer consumption per ha. $(\mathrm{kg})$ & $-V$. Low & + V. Low & -V. Low & + V. Low & $\mathrm{N} / \mathrm{A}$ & - V. Low \\
\hline Cereal yield per ha. $(\mathrm{kg})$ & $-V$. Low & + V. Low & + High & +Moderate & N/A & - V. Low \\
\hline Crops production index & + V. Low & +V. Low & $+V$. Low & + Low & $\mathrm{N} / \mathrm{A}$ & + V. Low \\
\hline Food production index & + V. Low & + V. Low & + Low & +Moderate & $\mathrm{N} / \mathrm{A}$ & + V. Low \\
\hline Livestock production index & -V. Low & +V. Low & + Low & + Low & $\mathrm{N} / \mathrm{A}$ & + V. Low \\
\hline $\mathrm{CO}_{2}$ emissions per capita (m.t.) & -Low & -Low & + Low & -V. Low & $\mathrm{N} / \mathrm{A}$ & -V. Low \\
\hline
\end{tabular}

Note. This matrix represents an evaluative summary of the correlations of variables shown in Figures A-3, A-5, A-6, A-7, and A-8; data values of the correlations are classified in five categories for positive and negative associations as: "No" relations $(0.00)$; $\mathrm{V}$. Low (less than or equal to $+/-0.20$ ); Low $(+/-0.21 \sim+/-0.40)$; Moderate $(+/-0.41 \sim+/-0.60)$; High $(+/-0.61 \sim+/-0.80)$; and V. High (+/- $0.81 \sim+/-1.00)$ - while "V." indicates "Very" and the high-income OECD countries having no ODA represent N/A (Not Applicable). 
Table 3

ODA in Billion US Dollars (B. US\$) and Variations, 1991-2011

\begin{tabular}{|c|c|c|c|c|c|c|c|c|}
\hline \multirow[b]{2}{*}{ Region/Group } & \multicolumn{2}{|c|}{1991} & \multicolumn{2}{|c|}{2001} & \multicolumn{2}{|c|}{2011} & \multicolumn{2}{|c|}{ ODA changed, $\%$} \\
\hline & $\begin{array}{l}\text { Country } \\
\text { (Count) }\end{array}$ & $\begin{array}{l}\text { ODA, B. } \\
\text { US\$ }\end{array}$ & $\begin{array}{l}\text { Country } \\
\text { (Count) }\end{array}$ & $\begin{array}{l}\text { ODA, B. } \\
\text { US\$ }\end{array}$ & $\begin{array}{l}\text { Country } \\
\text { (Count) }\end{array}$ & $\begin{array}{l}\text { ODA, B. } \\
\text { US\$ }\end{array}$ & $\begin{array}{l}\text { In 2001 } \\
(1991-2001)\end{array}$ & $\begin{array}{l}\text { In } 2011 \\
(1991-2011)\end{array}$ \\
\hline All countries & 160 & 87.55 & 172 & 74.22 & 140 & 93.84 & -15.2 & 7.2 \\
\hline \multicolumn{9}{|l|}{ Countries by income group: } \\
\hline Low income & 29 & 16.78 & 30 & 16.44 & 31 & 37.49 & -2.0 & 123.4 \\
\hline Lower middle income & 45 & 42.40 & 50 & 33.33 & 50 & 38.38 & -21.4 & -9.5 \\
\hline Upper middle income & 46 & 17.19 & 51 & 16.63 & 50 & 17.60 & -3.3 & 2.4 \\
\hline High income-non-OECD & 32 & 2.92 & 32 & 4.05 & 8 & 0.22 & 38.8 & -92.5 \\
\hline High income-OECD & 8 & 8.26 & 9 & 3.77 & 1 & 0.15 & -54.4 & -98.1 \\
\hline \multicolumn{9}{|l|}{ Countries by region: } \\
\hline East Asia \& Pacific & 30 & 12.25 & 30 & 12.55 & 23 & 6.81 & 2.5 & -44.4 \\
\hline Europe \& Central Asia & 20 & 11.07 & 29 & 15.05 & 18 & 9.41 & 36.0 & -14.9 \\
\hline Latin America \& Caribbean & 36 & 7.86 & 36 & 8.10 & 30 & 9.04 & 3.1 & 15.1 \\
\hline Middle East \& North Africa & 20 & 18.37 & 21 & 7.98 & 13 & 10.20 & -56.6 & -44.5 \\
\hline North America & 1 & -0.01 & 1 & 0.00 & 0 & 0.00 & -100.6 & -100.0 \\
\hline South Asia & 8 & 12.18 & 8 & 9.12 & 8 & 16.57 & -25.1 & 36.1 \\
\hline Sub-Saharan Africa & 45 & 25.84 & 47 & 21.42 & 48 & 41.81 & -17.1 & 61.8 \\
\hline
\end{tabular}

Note. Source of data is the World Bank (1991-2011) as retrieved and analyzed from (http://data.worldbank.org/indicator).

Table 4

Labour Populations (LP) and Changes, 1991-2011

\begin{tabular}{lllllllll}
\hline \multirow{2}{*}{ Region/Group } & \multicolumn{3}{c}{1991} & \multicolumn{2}{c}{2001} & \multicolumn{2}{c}{2011} & \multicolumn{2}{c}{ LP changed, \% } \\
\cline { 2 - 8 } & $\begin{array}{l}\text { Country } \\
\text { (Count) }\end{array}$ & LP, \% & $\begin{array}{l}\text { Country } \\
\text { (Count) }\end{array}$ & LP, \% & $\begin{array}{l}\text { Country } \\
\text { (Count) }\end{array}$ & LP, \% & $\begin{array}{l}\text { In 2001 } \\
(1991-2001)\end{array}$ & $\begin{array}{l}\text { In 2011 } \\
(1991-2011)\end{array}$ \\
\hline All countries & 185 & 67.2 & 185 & 67.7 & 185 & 68.5 & 0.5 & 1.3 \\
Countries by income group: & & & & & & & & \\
Low income & 30 & 74.9 & 30 & 75.1 & 30 & 76.5 & 0.2 & 1.6 \\
Lower middle income & 48 & 65.3 & 48 & 64.9 & 48 & 64.1 & -0.4 & -1.1 \\
Upper middle income & 47 & 62.3 & 47 & 63.4 & 47 & 64.0 & 1.1 & 1.7 \\
High income-non-OECD & 28 & 67.7 & 28 & 68.6 & 28 & 70.5 & 0.9 & 2.8 \\
High income-OECD & 32 & 69.7 & 32 & 70.6 & 32 & 72.7 & 0.9 & 3.0 \\
Countries by region: & & & & & & & & -1.1 \\
East Asia \& Pacific & 29 & 70.8 & 29 & 71.0 & 29 & 69.7 & 0.2 & 0.1 \\
Europe \& Central Asia & 48 & 69.0 & 48 & 68.3 & 48 & 69.1 & -0.7 & 4.4 \\
Latin America \& Caribbean & 31 & 64.9 & 31 & 67.5 & 31 & 69.2 & 2.6 & 2.8 \\
Middle East \& North Africa & 21 & 53.6 & 21 & 54.4 & 21 & 56.4 & 0.8 & -0.9 \\
North America & 2 & 75.8 & 2 & 76.1 & 2 & 74.9 & 0.3 & 2.1 \\
South Asia & 8 & 63.2 & 8 & 63.6 & 8 & 65.3 & 0.4 & 1.4 \\
Sub-Saharan Africa & 46 & 71.1 & 46 & 71.6 & 46 & 72.5 & 0.4 & \\
\hline
\end{tabular}

Note. Source of data is the World Bank (1991-2011) as retrieved and analyzed from (http://data.worldbank.org/indicator).

The proportion of the rural population, the labour force population active in agriculture, and the agriculture value added in GDP being dropped significantly although GDP per capita demonstrates a recurrent growth in recent decades in the global context. On an average, countries in East Asia and Pacific, North America, and the lower middle-income group had undulating risks of a $1 \%$ decline in labour while other regional and income group countries demonstrate a consequent increase in the labour force in 2011 as compared with 1991 (see Table 4). ODA effectiveness in food production index is relatively healthier merely in 
the high-income non-OECD countries than the other income group countries and the global context. Interestingly, the labour force populations versus net development assistance have a significant association with a correlation value $r=0.93$ in the high-income non-OECD countries (see Figure A-5) and a moderate association with a correlation value $r=0.55$ in the low-income countries (see Figure A-6).

\section{Trends in Agriculture Lands, Yields, and Values: Global, Regional and Income Group Countries}

Past agrarian structure in global context indicates that the higher income group countries had an aggregate declined 2.8\% (OECD - 4.1\% and non-OECD - 1.4\%) agriculture lands while in Sub-Saharan Africa countries in regional context had increased 3.4\% agriculture lands although the world's agriculture lands had increased 1.3\% of the total land area in 2011 as compared with 1991 (see Table 5). The opportunity of new agriculture lands remained had increased $5.2 \%$ in the low-income countries and $4.0 \%$ in the lower-middle-income countries. Ultimately, agriculture land areas, rural population, and the agriculture value in GDP are the major decays in the agriculture and rural development component especially after the year 2001 as exhibited for the data from 1991 to 2011 . The yearly decreasing rate of the world rural population and agriculture value added in GDP is respectively $0.28 \%$ and $0.46 \%$ (see Figure 1). Empirical analyses of variates demonstrate that the relationship of the rural occupancies and the agriculture value added in GDP is significant. That is, the relationship between rural population and agriculture value in GDP is extremely associated as where the "p-value" is 0.011 (Moore, 2010; Terrel, 2012). That is, the higher the rural populations enable, the higher the agriculture value added in GDP; in other words, the trends of the proportion of the rural population and the agricultural value added in the GDP are downwards and empirically parallel.

Table 5

Percent of Agriculture Land Areas (AL) of Total Lands and Changes, 1991-2011

\begin{tabular}{lllllllll}
\hline \multirow{2}{*}{ Region/Group } & \multicolumn{3}{c}{1991} & \multicolumn{2}{c}{2001} & \multicolumn{2}{l}{2011} & \multicolumn{2}{l}{ AL changed, \% } \\
\cline { 2 - 8 } & $\begin{array}{l}\text { Country } \\
\text { (Count) }\end{array}$ & AL, \% & $\begin{array}{l}\text { Country } \\
\text { (Count) }\end{array}$ & AL, \% & $\begin{array}{l}\text { Country } \\
\text { (Count) }\end{array}$ & AL, \% & $\begin{array}{l}\text { In 2001 } \\
(1991-2001)\end{array}$ & $\begin{array}{l}\text { In 2011 } \\
(1991-2011)\end{array}$ \\
\hline All countries & 180 & 36.8 & 204 & 38.3 & 206 & 38.1 & 1.5 & 1.3 \\
Countries by income group: & & & & & & & & 5.2 \\
Low income & 29 & 44.5 & 30 & 46.6 & 30 & 49.7 & 2.2 & 4.0 \\
Lower middle income & 43 & 38.5 & 50 & 42.4 & 50 & 42.4 & 3.9 & 1.7 \\
Upper middle income & 45 & 38.8 & 51 & 40.9 & 53 & 40.5 & 2.1 & -1.4 \\
High income-non-OECD & 37 & 22.0 & 41 & 21.9 & 41 & 20.6 & -0.1 & -4.1 \\
High income-OECD & 26 & 42.8 & 32 & 41.0 & 32 & 38.7 & -1.8 & -0.2 \\
Countries by region: & & & & & & & & 0.1 \\
East Asia \& Pacific & 35 & 27.3 & 35 & 27.3 & 35 & 27.1 & -0.1 & -1.9 \\
Europe \& Central Asia & 29 & 43.3 & 52 & 44.4 & 54 & 43.4 & 1.1 & 0.6 \\
Latin America \& Caribbean & 38 & 32.9 & 38 & 32.1 & 38 & 31.0 & -0.9 & -1.0 \\
Middle East \& North Africa & 21 & 32.4 & 21 & 34.1 & 21 & 33.0 & 1.7 & -0.1 \\
North America & 3 & 20.0 & 3 & 20.2 & 3 & 19.0 & 0.2 & 3.4 \\
South Asia & 8 & 43.5 & 8 & 44.1 & 8 & 43.4 & 0.5 & 1.9 \\
Sub-Saharan Africa & 46 & 44.9 & 47 & 46.8 & 47 & 48.3 & & \\
\hline
\end{tabular}

Note. Source of data is the World Bank (1991-2011) as retrieved and analyzed from (http://data.worldbank.org/indicator).

Figure 2 describes the spatial relationship of agriculture value added in GDP with the three dominant factors such as rural population, agriculture land areas, and the active labour force in 2011. High-income countries commonly have urban-centric active labour force (71.6\%) however extremely represent the lower agriculture 
value in GDP (4.7\%). From 1991 to 2011, the agriculture value added to GDP had decreased 8\% globally as South Asia barred the highest declined (12.5\%) followed by the Europe and the Central Asia (10.6\%). The North America, mainly because of a $2 \%$ increase in Bermuda, had an aggregate increase (1.0\%) in the rural lands (see Table 5). The higher the proportions of the rural population have a positive association with, the higher ratio of agriculture value added in GDP. On average, countries are in the low income and middle-income groups accumulated a typically increased portion of agriculture lands (4.6\%) while the high-income countries declined the agriculture lands $(2.8 \%)$ of total land areas because of the ongoing urbanization processes of rural lands. Similarly, rural population and labour population migrated to the urban compound are unevenly distributed. This situation continues as a result of summative population density, prolific industrial augmentation, and the huge urban settings that compel the varied land transits and community services.
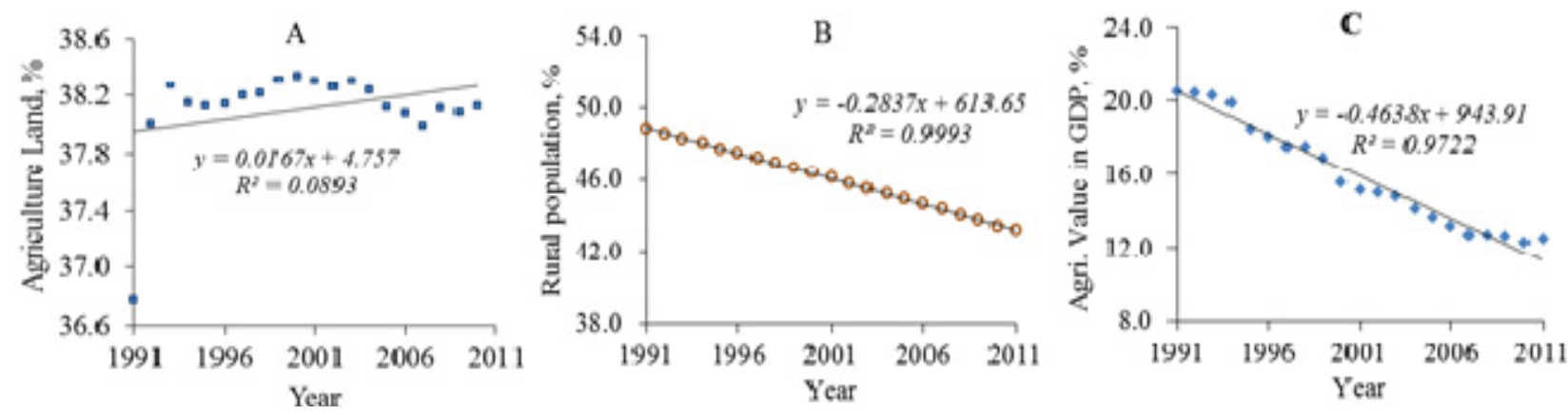

Figure 1. Trends of the three relative indicators: A. agriculture lands; B. rural populations; and C. agriculture value added in GDP (Data Source: World Bank, 2015; http://data.worldbank.org/indicator).
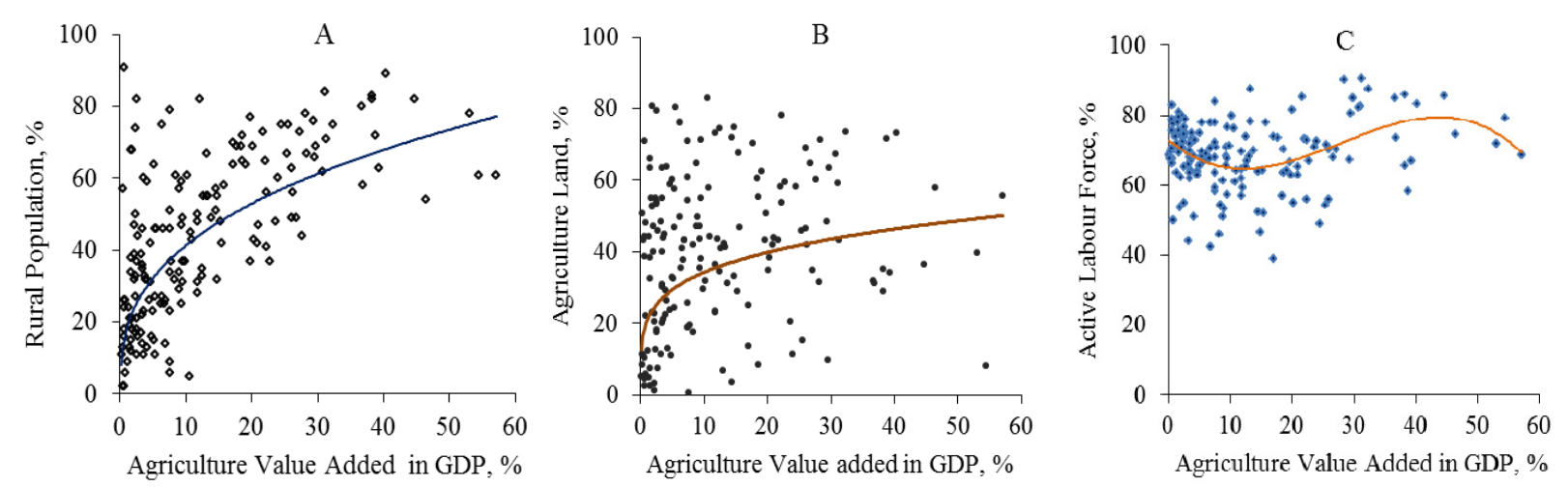

Figure 2. X-Y plots showing the relationship of agriculture value added in GDP with A. proportions of rural population of total population in percent; B. percent of agriculture land areas of total lands; C. proportion of labour population aged 15-64 in percent, with a possible data outlier, in 2011 (Data Source: World Bank, 2015; http://data.worldbank.org/indicator).

Figure 3 is a relative distribution of the spatial relationship between the active labour force and the agriculture value added in GDP. It demonstrates that the ultimate indicator in agriculture value added in GDP is a continual decline while GDP per capita is growing assuming that the income group countries remained same in 1991 and 2001 as in 2011 demonstrated in Figure 4. The analogies and interpretations of trends in agriculture and rural development moreover necessitate rethinking the issues toward the sustainable development patterns at least in three aspects: agriculture land holding and productivity; irrigation development and poverty reduction; land registrations and real-time data automation. 


\section{Agriculture Land Holding and Productivity}

The fringes of agriculture and its productivity, especially in low and lower-middle-income countries, are analogous to the regional and global context to convey the agriculture land holdings with the designated explanatory indicators. Conversely, higher infrastructure development areas reflect the lesser land holdings distribution, lower farming-size as well. We can pave the way of agriculture productivity up in exploration which is twofold: total cropped land area and yield per hectare per year. A total cropped area (TCA) represents crops-calendar or the cropping pattern of the crops grown and the "cropping intensity" (Mondal, Begum, Aziz, \& Sharif, 2015, p. 136; Jain, Mondal, DeFries, Small, \& Galford, 2013, p. 214) in a year. The net cultivable area (NCA) is required for cereal and minor crops cultivation to the sustainable agriculture and rural occupancies without conversions of agriculture lands to the alternative purpose such as settlements, urban or commercial zones.

In fact, the share of GDP value from agriculture depends on rural occupancies. Countries having an increasing amount of both the ODA (see Table 3) and the proportion of agriculture lands (see Table 4) unveil downward trends in agriculture value in GDP. Correlations between ODA and these variables in the rural infrastructures and the agriculture outputs are negative or insignificant (see Figure A-3 A-8).
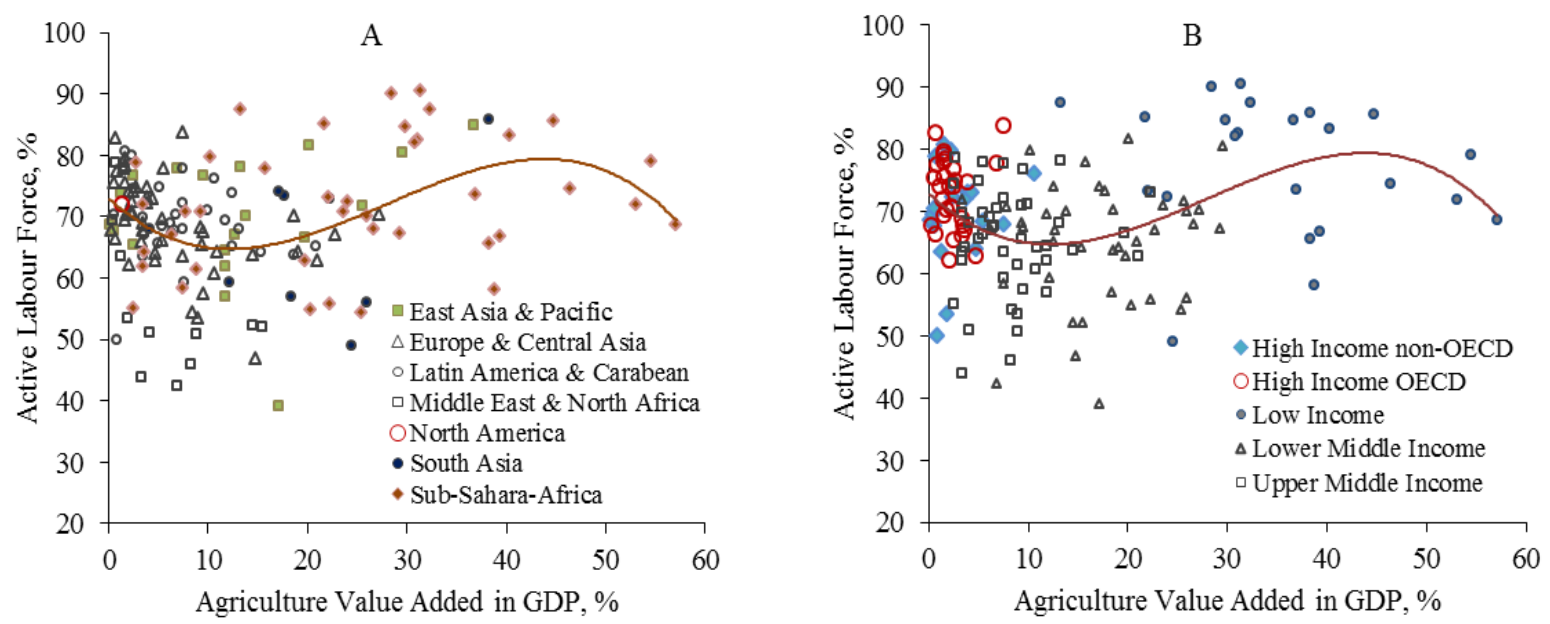

Figure 3. The spatial relationship between active labour force and agriculture value added in GDP countries by A. region; and B. income group, 2011 (Data Source: World Bank, 2015; http://data.worldbank.org/indicator).
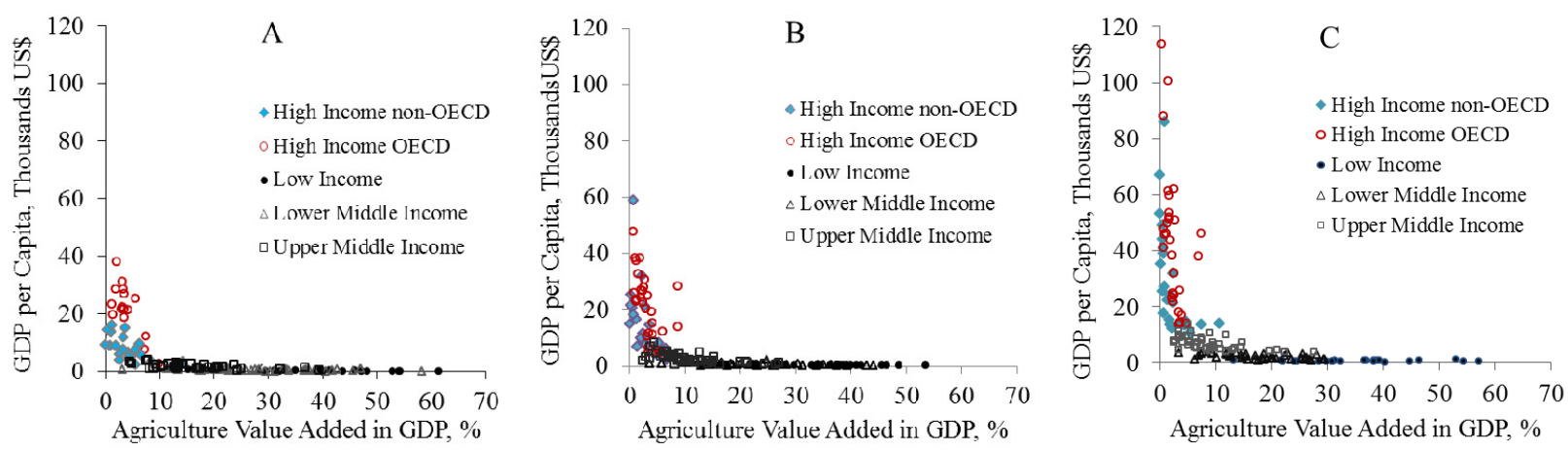

Figure 4. X-Y plots showing the relationship and change dynamics between agriculture value added in GDP and GDP per capita showing the world countries by income group: A (1991), B (2001), and C (2011) - assuming that the countries group in 2011 remained same as the regions in 1991 and 2001 (Data Source: World Bank, 2015; http://data.worldbank.org/indicator). 
Nevertheless, to meet the development challenges of a country, the international development assistance is imperative to improve public assets with accessible infrastructure as a prior development initiative that cumulatively affects agriculture production and the rural development. It is the case that where the development assistances are operative on rural infrastructure regardless to the acceleration of food-crops-production index that is accumulative to the shrewdness of local food security. Globally, even though the countries individually or by income group have a varied outcome with the development partnership, the effectiveness of ODA or net development assistance is not sagely constructive especially to the two vital rural development sectors: the rural infrastructure and the agriculture productions. The former is indication of the electricity access, safe water, and improved sanitation whereas the later has to be tied up to the suitable crops, foods, and livestock supplies that should be sustainable with agriculture policy standards comprising the socio-legal compliances and the regional economic cooperation for country-level food security.

The Middle-east and North Africa region mostly in the high-income non-OECD countries had increased $273 \%$ cereal crops yields per hectare in 2011 than that of 1991 (see Table 6). On the contrary, the region also had $6.9 \%$ declined in agriculture value added in GDP (see Table 7) and $18.2 \%$ declined in rural population (see Table 8). This synergy indicates that the countries in the Middle-east and North Africa region are also rapidly declining the rural occupancies after the North America exclusively Canada and the USA.

A principal goal of a country is to adopt the strategies of an "integrated food security". In 2006, Food and Agriculture Organization (FAO) performed a phase classification manual signifying the food vulnerability situation of a country (IPC Global Partners, 2008). Long-term sustainability of land productivity is almost extinct due to lack of aptness in land governance at the local level. Trends in food production index are increasingly downward. Moreover, agriculture productivity had been vulnerable because of unsuitable irrigation water (Karim, 2001) from either or the both surface water and the groundwater sources.

Table 6

Cereal Crops Yield (CY) per Ha. and Changes, 1991-2011

\begin{tabular}{|c|c|c|c|c|c|c|c|c|}
\hline \multirow[b]{2}{*}{ Region/Group } & \multicolumn{2}{|c|}{1991} & \multicolumn{2}{|c|}{2001} & \multicolumn{2}{|c|}{2011} & \multicolumn{2}{|c|}{ CY changed, $\%$} \\
\hline & $\begin{array}{l}\text { Country } \\
\text { (Count) }\end{array}$ & $\begin{array}{l}\text { CY per } \\
\text { ha. }\end{array}$ & $\begin{array}{l}\text { Country } \\
\text { (Count) }\end{array}$ & $\begin{array}{l}\text { CY per } \\
\text { ha. }\end{array}$ & $\begin{array}{l}\text { Country } \\
\text { (Count) }\end{array}$ & $\begin{array}{l}\text { CY per } \\
\text { ha. }\end{array}$ & $\begin{array}{l}\text { In } 2001 \\
(1991-2001)\end{array}$ & $\begin{array}{l}\text { In } 2011 \\
(1991-2011)\end{array}$ \\
\hline All countries & 150 & 2,265 & 177 & 2,689 & 178 & 3,639 & 18.7 & 60.6 \\
\hline \multicolumn{9}{|l|}{ Countries by income group: } \\
\hline Low income & 29 & 1,271 & 30 & 1,235 & 30 & 1,482 & -2.8 & 16.6 \\
\hline Lower middle income & 39 & 1,747 & 48 & 2,118 & 48 & 2,473 & 21.2 & 41.5 \\
\hline Upper middle income & 39 & 2,042 & 46 & 2,674 & 47 & 3,310 & 30.9 & 62.1 \\
\hline High income - non-OECD & 18 & 2,185 & 22 & 2,799 & 22 & 7,197 & 28.1 & 229.3 \\
\hline High income-OECD & 25 & 4,632 & 31 & 4,924 & 31 & 5,505 & 6.3 & 18.8 \\
\hline \multicolumn{9}{|l|}{ Countries by region: } \\
\hline East Asia \& Pacific & 23 & 2,865 & 24 & 3,149 & 24 & 3,575 & 9.9 & 24.8 \\
\hline Europe \& Central Asia & 22 & 4,399 & 46 & 3,791 & 47 & 4,380 & -13.8 & -0.4 \\
\hline Latin America \& Caribbean & 32 & 2,220 & 32 & 2,944 & 32 & 3,838 & 32.6 & 72.9 \\
\hline Middle East \& North Africa & 19 & 1,861 & 20 & 2,400 & 20 & 6,941 & 28.9 & 272.9 \\
\hline South Asia & 8 & 1,813 & 8 & 2,223 & 8 & 2,862 & 22.6 & 57.9 \\
\hline Sub-Saharan Africa & 44 & 1,116 & 45 & 1,281 & 45 & 1,360 & 14.8 & 21.8 \\
\hline
\end{tabular}

Note. Source of data is the World Bank (1991-2011) as retrieved and analyzed from (http://data.worldbank.org/indicator). 
Table 7

Agriculture Value (AV) in GDP and Changes, 1991-2011

\begin{tabular}{|c|c|c|c|c|c|c|c|c|}
\hline \multirow[b]{2}{*}{ Region/Group } & \multicolumn{2}{|c|}{1991} & \multicolumn{2}{|c|}{2001} & \multicolumn{2}{|c|}{2011} & \multicolumn{2}{|c|}{ AV in GDP changed, $\%$} \\
\hline & $\begin{array}{l}\text { Country } \\
\text { (Count) }\end{array}$ & $\mathrm{AV}, \%$ & $\begin{array}{l}\text { Country } \\
\text { (Count) }\end{array}$ & $\mathrm{AV}, \%$ & $\begin{array}{l}\text { Country } \\
\text { (Count) }\end{array}$ & $\mathrm{AV}, \%$ & $\begin{array}{l}\text { In 2001 } \\
(1991-2001)\end{array}$ & $\begin{array}{l}\text { In 2011 } \\
(1991-2011)\end{array}$ \\
\hline All countries & 142 & 20.5 & 177 & 15.2 & 171 & 12.4 & -5.4 & -8.1 \\
\hline \multicolumn{9}{|l|}{ Countries by income group: } \\
\hline Low income & 22 & 40.0 & 24 & 35.2 & 23 & 35.4 & -4.8 & -4.7 \\
\hline Lower middle income & 43 & 28.4 & 49 & 23.1 & 43 & 17.6 & -5.3 & -10.7 \\
\hline Upper middle income & 40 & 16.5 & 49 & 11.0 & 48 & 8.7 & -5.5 & -7.7 \\
\hline High income-non-OECD & 21 & 4.2 & 25 & 2.7 & 27 & 2.3 & -1.5 & -1.9 \\
\hline High income-OECD & 16 & 4.0 & 30 & 3.3 & 30 & 2.4 & -0.7 & -1.6 \\
\hline \multicolumn{9}{|l|}{ Countries by region: } \\
\hline East Asia \& Pacific & 24 & 19.4 & 28 & 17.3 & 25 & 13.4 & -2.1 & -6.0 \\
\hline Europe \& Central Asia & 28 & 17.0 & 48 & 9.7 & 49 & 6.4 & -7.3 & -10.6 \\
\hline Latin America \& Caribbean & 30 & 12.5 & 34 & 8.5 & 35 & 7.5 & -4.0 & -5.0 \\
\hline Middle East \& North Africa & 13 & 12.9 & 15 & 9.5 & 11 & 6.0 & -3.4 & -6.9 \\
\hline North America & & & 2 & 1.0 & 2 & 1.1 & 1.0 & 1.1 \\
\hline South Asia & 6 & 32.2 & 7 & 23.0 & 8 & 19.8 & -9.3 & -12.5 \\
\hline Sub-Saharan Africa & 41 & 30.2 & 43 & 26.5 & 41 & 24.2 & -3.7 & -6.0 \\
\hline
\end{tabular}

Note. Source of data is the World Bank (1991-2011) as retrieved and analyzed from (http://data.worldbank.org/indicator).

Table 8

Rural Populations (RP) and Changes, 1991-2011

\begin{tabular}{|c|c|c|c|c|c|c|c|c|}
\hline \multirow[b]{2}{*}{ Region/Group } & \multicolumn{2}{|l|}{1991} & \multicolumn{2}{|l|}{2001} & \multicolumn{2}{|l|}{2011} & \multicolumn{2}{|c|}{ RP changed, $\%$} \\
\hline & $\begin{array}{l}\text { Country } \\
\text { (Count) }\end{array}$ & $\mathrm{RP}, \%$ & $\begin{array}{l}\text { Country } \\
\text { (Count) } \\
\end{array}$ & $\mathrm{RP}, \%$ & $\begin{array}{l}\text { Country } \\
\text { (Count) }\end{array}$ & $\mathrm{RP}, \%$ & $\begin{array}{l}\text { In 2001 } \\
(1991-2001)\end{array}$ & $\begin{array}{l}\text { In } 2011 \\
(1991-2011) \\
\end{array}$ \\
\hline All countries & 204 & 499.1 & 204 & 46.4 & 204 & 43.4 & -5.6 & -11.6 \\
\hline \multicolumn{9}{|l|}{ Countries by income group: } \\
\hline Low income & 31 & 75.5 & 31 & 72.4 & 31 & 68.4 & -4.2 & -9.4 \\
\hline Lower middle income & 50 & 63.5 & 50 & 60.7 & 50 & 57.2 & -4.4 & -9.8 \\
\hline Upper middle income & 53 & 46.3 & 53 & 42.5 & 53 & 38.4 & -8.3 & -17.0 \\
\hline High income-non-OECD & 38 & 32.0 & 38 & 30.4 & 38 & 29.6 & -5.1 & -7.5 \\
\hline High income-OECD & 32 & 25.9 & 32 & 24.3 & 32 & 22.1 & -6.4 & -14.6 \\
\hline \multicolumn{9}{|l|}{ Countries by region: } \\
\hline East Asia \& Pacific & 33 & 53.2 & 33 & 50.0 & 33 & 45.8 & -5.9 & -13.9 \\
\hline Europe \& Central Asia & 54 & 37.1 & 54 & 36.1 & 54 & 34.6 & -2.6 & -6.7 \\
\hline Latin America \& Caribbean & 38 & 42.4 & 38 & 39.2 & 38 & 37.0 & -7.6 & -12.9 \\
\hline Middle East \& North Africa & 21 & 30.4 & 21 & 27.3 & 21 & 24.9 & -10.2 & -18.2 \\
\hline North America & 2 & 23.5 & 2 & 20.5 & 2 & 19.0 & -12.8 & -19.1 \\
\hline South Asia & 8 & 79.1 & 8 & 75.8 & 8 & 70.5 & -4.3 & -10.9 \\
\hline Sub-Saharan Africa & 48 & 69.3 & 48 & 65.5 & 48 & 61.4 & -5.4 & -11.4 \\
\hline
\end{tabular}

Note. Source of data is the World Bank (1991-2011) as retrieved and analyzed from (http://data.worldbank.org/indicator).

\section{Irrigation Development and Poverty Reduction}

Most of the countries in the middle- and low-income groups succeeded the irrigation development projects either or both with domestic and international support at the small-scale sourcing the groundwater (e.g., deep tube well irrigation) and large scale with surface water (e.g., canal irrigation) programs. The relevance of rural 
electrification likewise is to support the irrigation schemes for the agriculture development. A significant relationship between the irrigation development and the poverty reduction arouses the prevailing constraints in crops production predominant with the cultivators, institutions, and markets and prices - as a result of agriculture stagnation and to the slower poverty reduction after a certain stage. Lack of long-term service effectiveness of irrigation programs gradually lowered the agricultural productivity even though there had been a tremendous improvement and simultaneous use of irrigation mechanisms, hybrid seeds and fertilizer inputs to increase the agriculture crops production.

The key factors of land governance and agriculture development relate the prevailing impediments in agriculture financing, agriculture production, local foods and the ecological stability. Examination of local level agriculture lands necessitates the intervention of the effectiveness of certain irrigation facilities despite the countries like China, Vietnam, and Bangladesh demonstrated a significant irrigation development in agriculture in the earlier decades. Nonetheless, the irrigation development in this epoch had been disrupted by the unavailability of long-term water, lack of efficient fuel consumptions, and timeliness in electricity supply. On the other hand, the erstwhile irrigation development schemes were unsuccessful due to social, legal, environmental factors. Clearly, most of the irrigation programs, especially in the low-income and the lower middle-income countries, had collapsed in continuing the trends in poverty reduction mostly because of two reasons: the land use conversion and the environmental aptness degradation. Land use is an increasing transformation of rural lands to the newly built rural housing and settlements, commercial or industrial zones, and the urban compounds. The lowering of groundwater table and the scarce of optimal surface water level or the extent of salinity prone areas are extremely threats to the environment and the ecological agriculture. Policy options in agriculture and rural infrastructure development ought to be pertinent with data automation by pilot exercise to validate institutional, social, and legal compliances prior to conceiving the liability of financial agreement for massive tasks.

\section{Land Registrations and Real-Time Data Automation}

Although the technological interventions of land resources and information using mobile broadband applications enable a country's land registration system to concede, in particular, the open-source tools, its use is an oddity to the real-time land registration and data automation system because of outsourcing and inaptness in digital technology and data management protocols. Mobile broadband apps in land resources and technology are moot at least to the three unexpected problems, however, are useful for the rapid update at the post-land registration period. The problems are the accessibility of mobile network in the remote areas; data storage and data transfer speed capacity; and data registration accuracy on the scale, that is, the "modifiable area" and the "ground resolution". The fundamental disadvantage of the mobile broadband apps in land registration is that this technology is yet not autonomously capable of running a high volume of data storage and a sustainable mobile network in the desired time-frame that is necessary at the remote areas connecting the designated data applications. Ground resolution and data scale are indispensable in local land records.

For example, land parcels are characterized by integrating the confirmations of data verified by the desired numbers of the ground control points (GCPs), the differential GPS (global positioning system) application, and high-resolution satellite imagery that nowadays is dense with sub-meter accuracy data of a land surface. Satellite imagery is useful to identify the land use and land cover change dynamics with vegetation index (Setiawan \& Yoshino, 2012; Masek, Honzak, Goward, Liu, \& Pak, 2001) and agriculture suitability and cropping pattern (Jain et al., 2013; Verburg \& Veldkamp, 2001) in a delineated land area. Moreover, agriculture suitability 
assessment in the wetlands or fairly an abrupt land area is affected by inundations because of excessive precipitations or late water recessions. It commonly entails land cover pre-classifications with Principal Component Analysis (PCA) to determine the convolutions of ground conditions estimated by eigenvalues and eigenvectors from a desired multispectral satellite image (Munyati, 2004; Wulder, White, Coops, \& Ortlepp, 2009).

Local land coverage data notice the rapid changes of agriculture lands to settlements, growth centers, urban corridors, or the commercial areas. Nonetheless, lessons learned from the local level land administration suggest that agriculture lands development ought to be assembling a policy framework from land use suitability in a region. The policy statement commonly refers regulations and acts that are designated for land use provisions to ease the persistent gaps between the municipal acts and rural development plans. Appraisal of location-specific land use suitability and monitoring regional land management should emphasize on indicative agriculture policy. In this case, the integrated land governance would comprise at least four purposeful necessities: (1) agriculture land use delineations; (2) soil and water quality assessment; (3) social and environmental impact assessment; and (4) legal, institutional, and policy compliance. Despite local constraints are prevalent in the rural occupancies including the land tenures, retaining the admissible and effective agriculture lands to sustain the food crops yields would be justifiable as a key aspect of land governance.

\section{Agriculture and Rural Occupancies Constraints: A Country-Level Instance}

Intending to sensitize the lessons learned from the institutional knowledge particularly in the least developed or developing country is inexorable. This section briefly expounds to some extent any circumstance consequent to agriculture, local government, and the rural development sectors. Agriculture food crops production in the low-income or lower-middle-income countries where a technological application is rarely available is dignified chiefly by nature and the farmers. Merely the agriculture households' workers with a little or no technical implications struggling the farming situations with droughts, floods, and vicious storms play vital role in the agricultural sector crops production. Commonly, the risks of agriculture land and crops productivity for any country are incessant rainfalls, floods, and violent storms. These occurrences are fast-tracked by geographical and environmental conditions. Nonetheless, the consequence of development association in service delivery in the agriculture and rural development programs is mostly unnoticed to the local community in many cases. The main reasons were:

(1) Invisible exit strategies of the development programs because of complexity in institutional settings, partnership agreements, and the liability sharing;

(2) Lack of prior "environmental impact assessment" including the validation of stakeholder engagements and the public consultations;

(3) Inadequate effects for long-term sustainability concerning a permissible portion of agriculture land areas of total lands.

Local constraints in the agricultural sector lands and the rural occupancies are twisted by the environment and human interventions. Even though environmental and local constraints predominantly limit agriculture intensity in Bangladesh, its agriculture sector value shared 58\% of GDP in the mid-1980s (Turner \& Ali, 1996, p. 14986). Nonetheless, recent decades show that the agriculture value added in GDP dropped from $38.2 \%$ in 1991 to $17.7 \%$ in $2011^{2}$. Country level review of data, according to the national population census records from 1960 to 2000 (Ahmed, 2007b) also indicated two negative trends in agriculture development. First, agriculture

${ }^{2}$ World Bank. (2015). Retrieved from http://data.worldbank $\backslash$ indicator. 
based total labour force had decreased $0.94 \%$ per year while the female labour population had declined $1.5 \%$ per year. Second, Mouza, the smallest revenue area, data indicate that agriculture working population is spatially auto-correlated with households' labour force in the rural occupancies. We can travel the intuition further at least in four aspects: (1) irrigation water and floods; (2) crops technology, production, and price; (3) agriculture landscape and land types; and (4) rural occupancies and safe water.

Irrigation water and floods. Primary sources for irrigating the agriculture lands were renowned for the groundwater and surface water in Bangladesh since the 1970s. Until 2006, nearly about 52\% areas of agriculture lands remained under irrigation water management and flood control, according to the World Bank's records in 2015. Over a decade, most of the rural lands operative by irrigation and drainage controls are now distorted as a result of the density of urban growths, intensity of new settlements, frequency of surface floods, and the scarce of river flow water or unsuitability of groundwater. Perhaps, change in agricultural land topography, cropping patterns, and the rural occupancies appeared drastically in the recent decades. Examples are the 1987s floods along the Atrai basin in the northern regions while Bangladesh-Canada Agriculture Sector Team conducted a field study in 1987, frequencies of floods and cyclone storms (UNB, 2007, p. 1; Ahmed, 2007b, p. 33), and hasty urban development processes including the local brick-kilns activities. Consequently, crops diversity comprising the minor crops acreage and production turns into restrained. The inferences also depreciate at least with two major impediments: the intrusion of surface water salinity in the floodplain agriculture lands, mainly the coastal regions plus the floodplain basins along the river Meghna; and lack of aptness in groundwater and surface water availability for the irrigated crops land across the country.

A major canal irrigation project, the Ganges-Kobatak Irrigation Systems Project (G-K project), appeared dysfunctional or had been performed lower because of failure to the minimal and maximum levels of threshold limit of water flow as caused by Farakka Barrage since 1975 (Gain \& Giupponi, 2014, p. 2510). India, a neighboring country of Bangladesh, constructed this massive cross-dam that arbitrarily withdrew the standard level of water in the Ganges water flow, especially in the dry season (December-May). As a result, G-K project appeared ineffective with an institutional flaw that rather constitutes dual consequences such as the deficiency of institutional agreement for rehabilitation of the irrigation system and lack of year around the standard level of river water discharge. Indeed, this huge irrigation project aimed at agriculture and rural occupancies covering an area of 141,000 hectares net irrigable lands proposes a total of 700,000 hectares including the rehabilitation phase [Asian Development Bank (ADB), 1998; Ali, 2001] in the southwestern region of the country.

Crops technology, production, and price. In 1988, the government of Bangladesh and UNDP/FAO (United Nations Development Program/Food and Agriculture Organization) steered a major sectoral study on agriculture including, food crops productions, markets and prices, and irrigation water (e.g., UNDP/FAO Project: Bangladesh Agriculture Sector Review-BGD/87/023-OPE/OPS). The pragmatism of a country-level agriculture, among other things, is that the farmers often face the critical situation of the cost-effectiveness of the crops grown and the turnaround time. According to the UN Food and Agriculture Organization (FAO), turnaround time is "the period between the harvesting of the preceding crop and planting of the succeeding crop in a specific field" which is also subject to completing availability of agriculture field equipment. Irrigation and Flood Control Wing of Bangladesh Agriculture Research Council (BARC) was the custodian for the technological interventions of agriculture laboratories, and the fields equipment for the National Agriculture Research System (NARS). BARC administered 11 national institutes [e.g., BARI (Bangladesh Agriculture Research Institute), BRRI (Bangladesh Rice Research Institute), etc.] and their regional and field offices that 
were rather unable to handle the enormous number of sophisticated equipment in full swing. While USAID (United States Agency for International Development) and other major development partners supported the agriculture development programs (e.g., NARS Equipment Inventory, Agricultural Research Project II (Supplement)/BARC-USAID, 1990-1991), the tiniest reasons behind the underutilization of the agriculture equipment were:

(1) Shortage of appropriate resource person in the designated department;

(2) Lack of professional or technical knowledge in handling the equipment;

(3) Inapt or obsolete equipment for the desired research in agriculture management.

Agriculture landscape and land types. Agriculture lands in Bangladesh are flood plains dominant and affected by the frequencies of floods and storms that often damage agriculture crops, rural settlements, and the public assets. With an emerging need, the country-wide necessities were to recover the water resources planning for infrastructure, agriculture, and rural and urban environments. Bangladesh Flood Action Plan (FAP) consisted of 26 components was principally operated to extend the government business effects majorly with the water resources planning associated with different sectors between 1991 and 1996. The component FAP-26 was the institutional part for housing the achievements of all other 25 FAP components to scope and implement the policy options at the local, regional, and national level. FAP-19 component (GIS study), among the other major local and regional analyses, applied spatial data management, including construction of the National Digital Elevation Model (DEM), to advise the country's water resources planning, infrastructure development, and environmental management (ISPAN/FAP-19-USAID, 1995). In effect, a crucial application of DEM (see Figure 5) is meaningfully useful to assess, among others, the topography (slopes and aspects) and topology (vectors and attributes) of agriculture lands, to estimate the crops damage due to floods, droughts, and land erosions (EGIS, 1997). These factors apparently bid to understand the characteristic of land surface and develop the environmental profile of crops suitability. Major crops especially the local paddy including high yield crops verities, e.g., of Aus, Amon, and Boro, grown in Bangladesh are concomitant with ecology, infrastructure, and settlement and permanent (spatial) and seasonal (temporal) water bodies. Decisively, no matter what it takes, the outputs derived from the flood actions plans activities strengthened at least the following institutional capacities:

(1) Brought spatial data management capability in the broad range of areas across the country;

(2) Developed various groups of experts with technical know-how in different fields;

(3) Enhanced the institutional capacity in government business in the respective sectors;

(4) Implemented flood forecasting models and options for indicative responses needed for infrastructure planning.

Rural occupancies and safe water. Various factual shreds of evidence reported that almost half of the groundwater aquifer contains arsenic and other toxic chemical pollutants and is noticeably unsafe both for irrigation and for domestic use since a decade. Such occurrences of groundwater pollutions affect "Holocene" aquifers at depths between $20 \mathrm{~m}$ and $120 \mathrm{~m}$ especially in the south-centre and east regions of the country (Seddique et al., 2008; Brammer \& Ravenscroft, 2009, p. 649). In 1998-1999, aiming the safe drinking water especially in the rural occupancies in Bangladesh, the Department of Public Health Engineering (DPHE) in collaboration with the British Geological Survey (BGS) supported by the British DFID (UK Department for International Development) carried out a rapid study of groundwater to support the local government and rural development. The investigation explored the severity of groundwater arsenic across the southern part of the country where $25 \%$ of domestic hand tube wells at the shallow depths (below $40 \mathrm{~m}$ ) contain the drinking water 
exceeded the standards of 50 micrograms of arsenic (As) per liter. This situation also affects typical irrigation water with acceptable quality and availability of groundwater for agriculture crops cultivation.
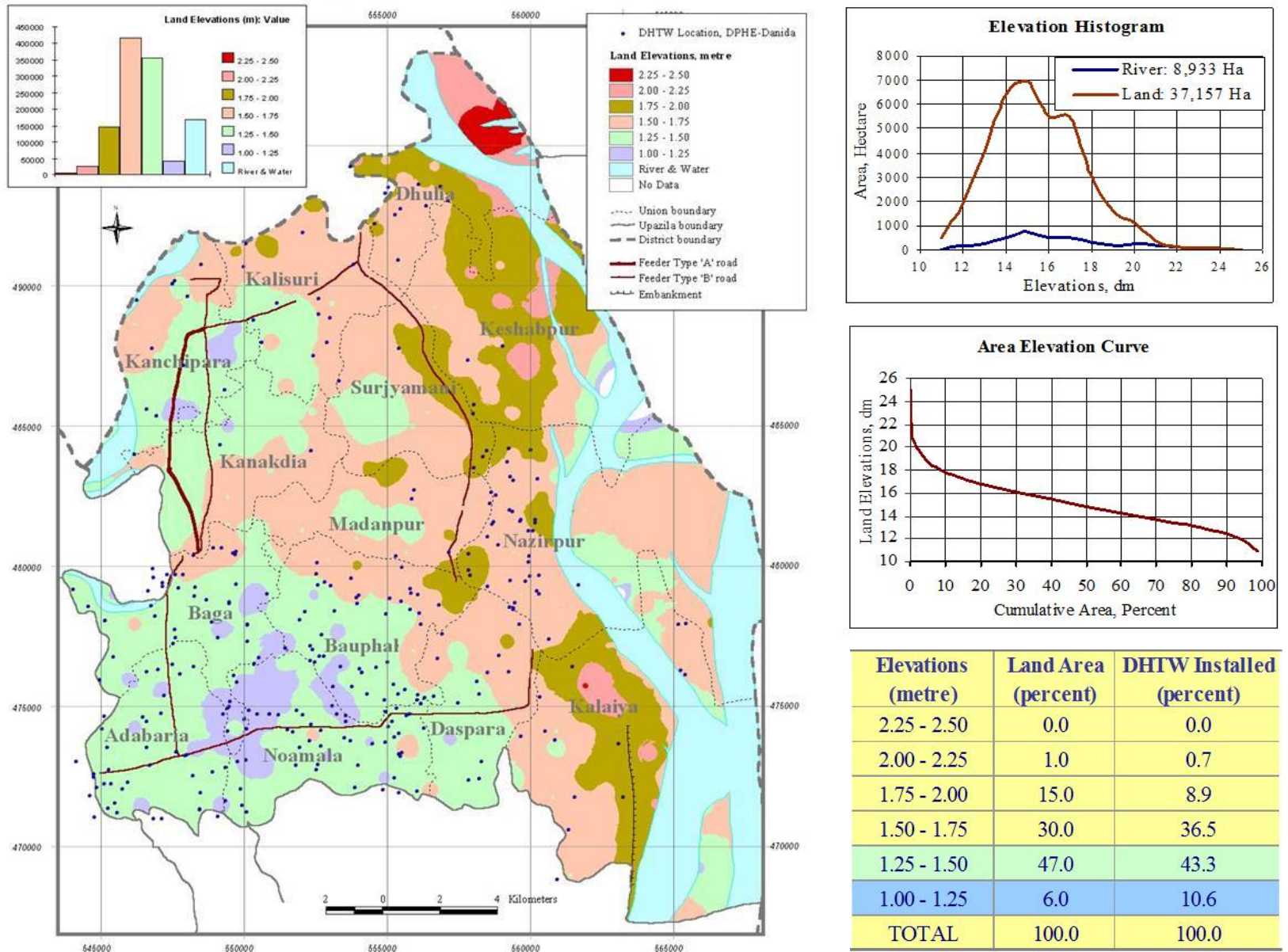

\begin{tabular}{c|c|c}
\hline $\begin{array}{c}\text { Elevations } \\
\text { (metre) }\end{array}$ & $\begin{array}{c}\text { Land Area } \\
\text { (percent) }\end{array}$ & $\begin{array}{c}\text { DHTW Installed } \\
\text { (percent) }\end{array}$ \\
\hline $2.25-2.50$ & 0.0 & 0.0 \\
\hline $2.00-2.25$ & 1.0 & 0.7 \\
\hline $1.75-2.00$ & 15.0 & 8.9 \\
\hline $1.50-1.75$ & 30.0 & 36.5 \\
\hline $1.25-1.50$ & 47.0 & 43.3 \\
\hline $1.00-1.25$ & 6.0 & 10.6 \\
\hline TOTAL & 100.0 & 100.0 \\
\hline
\end{tabular}

Figure 5. Digital Elevation Model (DEM) that characterizes the physical and environmental conditions of land facets indicating the risk of flood inundation from tidal surge, excessive rainfalls, or violent storms. It presents the land elevation surface with resampling grids $(50 \mathrm{~m} \times 50 \mathrm{~m}$ pixel) of National DEM (ISPAN/FAP-19-USAID, 1995), which was built primarily on $300 \mathrm{~m} \times 300 \mathrm{~m}$ and/or $100 \mathrm{~m} \times 300 \mathrm{~m}$ ground resolutions (spot elevations shown in the country's topographic contour maps, Bangladesh Water Development Board) generated with a land surface at $500 \mathrm{~m}$ pixel resolution. The relative indicators of this land surface are: determining a physical location, the designated land area, probable surface sinks and surface breaks such as permanent water bodies and/or river courses, and the classification ranges of land elevation indicating the maximum and minimum heights above the sea datum. The corresponding outputs are elevations histograms, area-elevation-curve, and a look-up table. Furthermore, DEM or land surface elevations and water surface depths are fundamentally useful to determine inundation land types in conjunction with soils associations' properties or the physiographic units in a domain. pcArc/Info, and ArcView GIS plus Spatial Analyst software were used to mark the program effectiveness in a designated area of water supply and sanitation component. Model Source: Author: May 29, 2003-DPHE-Danida Water Supply and Sanitation Components.

In 2000-2004, the local government and rural development efforts supported by the Danish International Development Assistance covered 35 Upazilas (sub-districts) including the designated local municipalities in the eight coastal districts. The water supply and sanitation components program was instigated to support the installations of more than 20,000 deep hand tube wells (DHTW) at depths between $150 \mathrm{~m}$ and $300 \mathrm{~m}$ to 
mitigate arsenic free drinking water to the pro-poor people and marginal farmers in the rural areas (DPHE-Danida WSSC, 2002). This solution rather adversely escalated an incremental risk of groundwater availability especially in the low-lying agriculture lands and the rural occupancy areas to the long-term needs despite the fact were decent to aiming an urgent mitigation for safe drinking water.

Understanding the landscape of a designated area is a fundamental requirement for implementation of the development program for agriculture and rural development components associated with land governance. For example, safe drinking water restoration can encompass the physical interventions, shown in Figure 5: (1) geo-registrations of the installed water spots with water quality data, using GPS surveys; (2) assessment of the program cost-effectiveness of the installed water spots; and (3) distinguish the sustainability of the safe drinking water spots concerning the topographical conditions.

Therefore, the interventions were:

(1) A designated area that comprised an area with 37,157 ha. plain lands and 8,933 ha. river water courses incorporated, e.g., 301 installed deep hand tube wells (drinking water spots);

(2) Fifty percent of the land areas represent $0-1.5 \mathrm{~m}$ land elevations above the sea datum;

(3) Six percent areas of total land surface retain $10.6 \%$ of the installed water spots would be under flood risk from water surges, and violent storms would need rehabilitation often in regular flood condition, that is, 1 in 2.33 years flood. The designated area has further worsened in the case of one-in-five years and one-in-ten years floods scenarios.

\section{Innovative Methods: Data Gathering and Agriculture Lands Delineation}

Agriculture data on crops acreage and production are inconsistent indeed across the world. The low-income countries and the middle-income countries mostly in the Europe and Central Asia and the South Asia regions demonstrate a higher decline in agriculture value in GDP (see Table 7). Local restraints associated with agriculture and rural development would habitually recognize the land governance accountability. Information management appraisal and policy planning with innovative technological attitude in such cases is obvious at the major steps of government business and partnership associations. Simply, if we recognize, these legs are pre-investment, operational, and post-investment phases of any development assistance or project delivery succession.

Exurbia husbandry and land tenures aggregate transition of wetland habitats and agriculture lands to the real estates and settlements development finally emerged the urban intensity. In contrast, local constraints in the agriculture areas and the rural occupancies appear critical for sustainable development goals in crops and food production and the rural livelihoods. The circumferences from the number of instances envisioned are parallel to the real-world grasps.

Many countries in the low- and middle-income groups would necessitate to unlock the potentials in innovative development of data gathering for responsible land governance, scaling of what is the past practice and lessons learned from the other countries. Most of the countries in South Asia, likely the other regions, are experienced with the change dynamics of agriculture land tenures. The key emphasis is the establishment of agriculture lands with ecological, topographical, and physiographic suitability. The tradition of an agro-ecological zone is hardly retained because of an urban-centric high population in the most of the countries. Undoubtedly, ideological development for organizing data and implementing the land delimitation would have compelled for permissible agriculture land and rural occupancies to adopt land zoning information management (Ahmed, 2007a) and policy for sustainable land management (see Figure 6). 


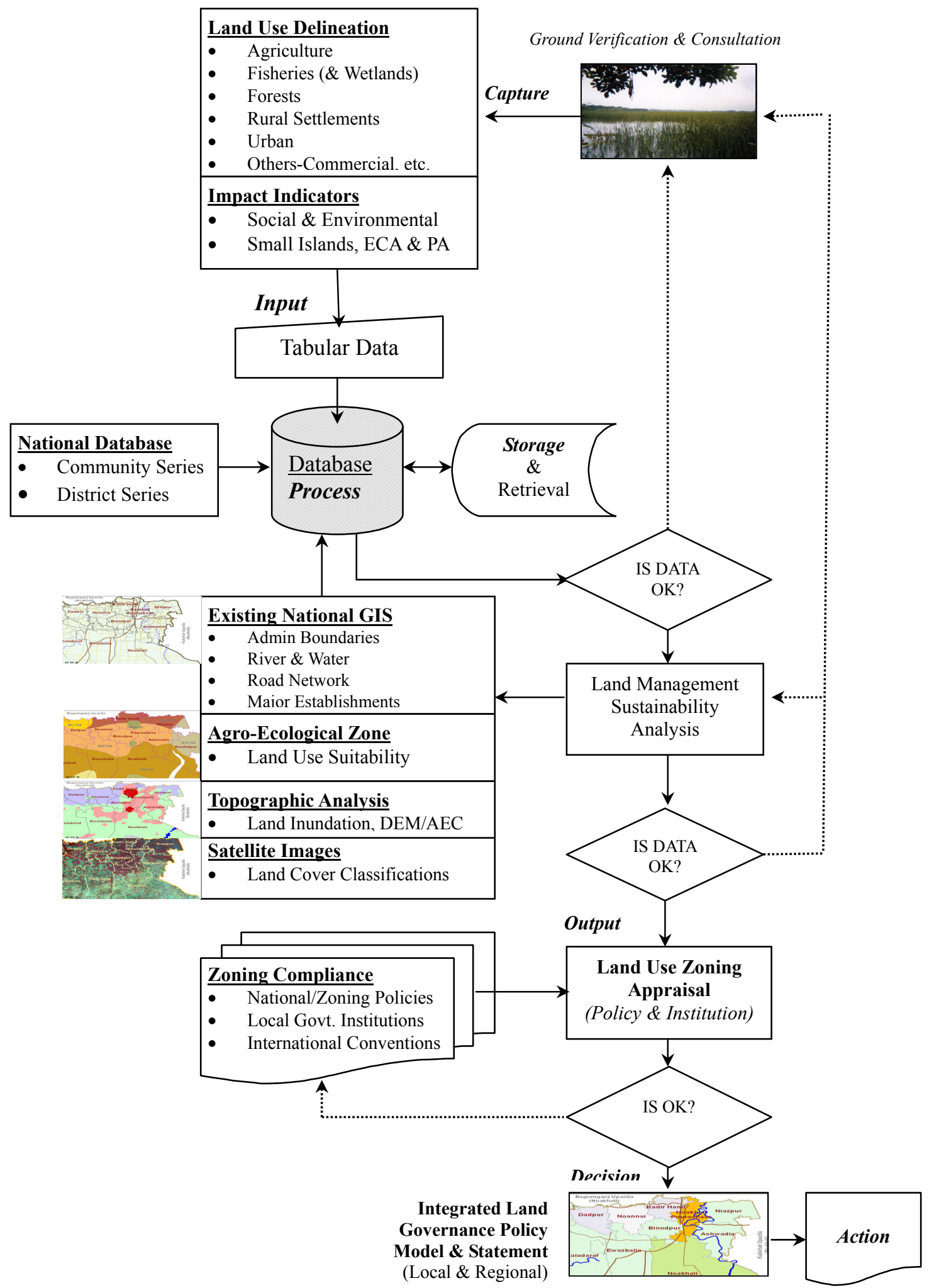

Figure 6. An illustration of a schematic flow of information for sustainable land management (Data Flow Model Source: Ahmed, 2007b). This model was represented in the topic "The key aspects of land governance: A policy framework for developing countries" as abstract in the Annual World Bank Conference on Land and Poverty, 2014, Poster Sessions, POS-07, p. 179. Here, ECA $\rightarrow$ ecologically critical area, and PA $\rightarrow$ protected area. 


\section{Conclusions}

In conclusions, analyses of historical agrarian data and the relative indicators characterize the land structure associated with the agriculture policy at least in four traits. First, the relationship between the agriculture value added in GDP and the cumulative official development assistance to the designated countries demonstrates undulating effect and is mostly incoherent. Second, highly populated countries are increasingly diminishing agriculture growth mainly due to the inefficient use of lands and low agriculture productivity. Third, in divergence, high-income countries are averse to maximize crops production because of the ongoing urbanization processes and the intergovernmental political economies, including labour migration and infrastructure development. Fourth, reviews of local level agriculture dependencies indicate that the higher the agriculture labour population exemplifies, the higher household labour population in the rural occupancies. Land management, in other words, responsible land governance needs to be scaling with an informed policy model capable of monitoring and appraising the impacts of sustainable agriculture land use and rural occupancies.

The government policy in decision-support-system should be accessible to precede the progressive examinations of both quantitative and qualitative information. Determination of the agriculture land uses policy indicators on the socio-economic, and agro-ecological perspectives is directive to the local level land habits. Land use delineation and multi-criteria evaluation with spatial data analysis aid to characterize the complex variables associated with land management. Over the passage of time, as perceived, the progression of a locality is rendered through the Growth Centre to municipal town and later to a municipal city area that disregards the necessity of agriculture and rural occupancies particularly at urban growing phases of the developed countries. This research offers some primary issues and corresponding functional areas for land governance recognizing the frontiers in agriculture policy paradigms. In particular, there should be an acceptable bid for a country to retain a mandatory portion of the agriculture land areas in a local or regional municipal jurisdiction to relate the persistence of rural occupancies to the agriculture value in GDP, to assure the local food crops security and to essentially comply with the SDGs' effect.

\section{References}

Agriculture and Agri-Food Canada. (2015). Impact of climate change on Canadian agriculture. Government of Canada. Retrieved from http:/www.agr.gc.ca/eng/science-and-innovation/agricultural-practices/climate/future-outlook/impact-of-climatechange-on-canadian-agriculture/?id=1329321987305

Ahmed, S. (2007a). Land zoning information management. In Inception report: Study of detailed coastal land zoning including two pilot districts of plain land project (pp. 153-169). Ministry of Land, Government of the People's Republic of Bangladesh.

Ahmed, S. (2007b). Land zoning impact and policy for sustainable land management. Unpublished MPA dissertation, Civil Service College, University of Dhaka, Bangladesh.

Ahmed, S. (2015). Environmental policy for road transportation: Greenhouse gas emissions and carbon lands nexus. Journal of US-China Public Administration, 12(5), 378-401.

Ali, N. M. (2001). Irrigation management issues in Bangladesh: Experiences and lessons from Ganges-Kobadak irrigation system. In I. Hussain and E. Biltonen (Eds.), Irrigation against rural poverty: An overview of issues and pro-poor intervention strategies in irrigated agriculture in Asia. Colombo, Sri Lanka: International Water Management Institute.

Asian Development Bank (ADB). (1998). Project performance audit report on the Ganges-Kobadak Irrigation Rehabilitation Project (Loan No. 671-BAN[SF]) in Bangladesh. Asian Development Bank. Retrieved from http://www.adb.org/sites/ default/files/evaluation-document/35312/files/pe499.pdf

Botkin, D. B., \& Keller, E. A. (2005). Environmental science: Earth as a living planet (5th ed.). Hoboken, NJ: John Wiley \& Sons, Inc. 
Brammer, H., \& Ravenscroft, P. (2009). Arsenic in groundwater: A threat to sustainable agriculture in South and South-East Asia. Environment International, 35(3), 647-654.

DPHE-Danida WSSCs. (2002). Deep hand tubewell installation GIS database: Framework and analysis. Dhaka: DPHE-Danida Water Supply and Sanitation Components, Danida Advisory Group.

EGIS. (1997). Regional environmental profile: Bangshi-Dhaleswari-Kaliganaga region. Dhaka: Delft Hydraulics, Environment and GIS Support Project for Water Sector Planning (EGIS).

Gain, A. K., \& Giupponi, C. (2014). Impact of the Farakka dam on thresholds of the hydrologic flow regime in the lower Ganges River basin (Bangladesh). Water 2014, 6, 2501-2518.

IPC Global Partners. (2008). Integrated food security phase classification technical manual (Version 1.1). Rome: FAO.

ISPAN/FAP-19-USAID. (1995). National digital elevation model: A 500 meter resolution land surface model of Bangladesh. Irrigation support project for Asia and the Neareast. Arlington, VA: ISPAN Technical Support Centre.

Jain, M., Mondal, P., DeFries, R. S., Small, C., \& Galford, G. L. (2013). Mapping cropping intensity of smallholder farms: A comparison of methods using multiple sensors. Remote Sensing of Environment, 134, 210-223.

Karim, Z. (2001). Role of irrigation towards achieving food self-sufficiency in Bangladesh. In I. Hussain and E. Biltonen (Eds.), Irrigation against rural poverty: An overview of issues and pro-poor intervention strategies in irrigated agriculture in Asia (pp. 25-28). Colombo: International Water Management Institute. Retrieved from http://ageconsearch.umn.edu/bitstream/ 118406/2/H028857.pdf\#page $=10$

Kogel, T., \& Prskawetz, A. (2000). Agricultural productivity growth and escape from the Malthusian trap. Rostock, Germany: Max Planck Institute for Demographic Research. Retrieved from http://www.demogr.mpg.de/Papers/Working/wp2000-002.pdf

Magdoff, F. (2007). Ecological agriculture: Principles, practices, and constraints. Renewable Agriculture and Food Systems, 22(2), 109-117.

Martens, M. D., \& Wilson, A. T. (2012). Program evaluation theory and practice: A comprehensive guide. New York, NY: Guilford Press.

Masek, J. G., Honzak, M., Goward, S. N., Liu, P., \& Pak, E. (2001). Landsat-7 ETM+ as an observatory for land cover: Initial radiometric and geometric comparisons with Landsat-5 Thematic Mapper. Remote Sensing of Environment, 78(1-2), 118-130.

Mondal, R. I., Begum, F., Aziz, A., \& Sharif, S. H. (2015). Crop sequences for increasing cropping intensity and productivity. SAARC Journal of Agriculture, 13(1), 135-147.

Moore, D. S. (2010). The basic practice of statistics (5th ed.). New York, NY: W. H. Freeman and Company.

Munyati, C. (2004). Use of Principal Component Analysis (PCA) of remote sensing images in wetland change detection on the Kafue Flats, Zambia. Geocarto International, 19(3), 11-22.

Rao, C. H. (1965, February 27). Agriculture growth and stagnation in India. The Economic Weekly, 407-412.

Sachs, J. D. (2008). Common wealth: Economics for a crowded planet. New York, USA: The Penguin Press.

Seddique, A., Masuda, H., Mitamura, M., Shinoda, K., Yamanaka, T., Itai, T., ... Biswas, D. K. (2008). Arsenic release from biotite into a holocene groundwater aquifer in Bangladesh. Applied Geochemistry, 23(8), 2236-2248.

Setiawan, Y., \& Yoshino, K. (2012). Change detection in land use and land cover dynamics at a regional scale from MODIS time-series imagery. ISPRS Annals of the Photogrammetry, Remote Sensing and Spatial Information Sciences, I-7, 243-248.

Terrell, S. R. (2012). Statistics translated: A step-by-step guide to analyzing and interpreting data. New York, USA: The Guilford Press.

The World Bank. (2006). Agriculture and achieving the millennium development goals. The World Bank-Agriculture and Rural Development, and International Food Policy Research Institute. Washington, D.C.: The World Bank. Retrieved from http://documents.worldbank.org/curated/en/2005/01/6654799/agriculture-achieving-millennium-development -goals\#

Todaro, M. P. (2000). Economic development. Don Mills, ON: Addison-Wesley.

Turner II, B. L., \& Ali, A. M. S. (1996). Induced intensification: Agricultural change in Bangladesh with implications for Malthus and Boserup. Proc. Natl. Acad. Sci. USA, 93(25), 14984-14991.

UNB (United News of Bangladesh). (2007, November 16). Major storms since 1822. The Daily Star, p. 1.

United Nations. (1992). Sustainable development: Agenda 21. Proceedings from United Nations Conference on Environment \& Development. June 3-June 14, Rio de Janerio, Brazil. 
United Nations. (2016). Report of the inter-agency and expert group on sustainable development goal indicators. Economic and Social Council, United Nations. Retrieved from http://unstats.un.org/unsd/statcom/47th-session/documents/2016-2-IAEGSDGs-E.pdf

Verburg, P. H., \& Veldkamp, A. (2001). The role of spatially explicit models in land-use change research: A case study for cropping patterns in China. Agriculture, Ecosystems and Environment, 85(1-3), 177-190.

Williamson, I., Enemark, S., Wallace, J., \& Rajabifard, A. (2010). Land administration for sustainable development. Redlands, CA: Esri Press.

Wulder, M. A., White, J. C., Coops, N. C., \& Ortlepp, S. (2009). Remote sensing for studies of vegetation condition: Theory and application. In T. A. Warner, M. D. Nellis, and G. M. Foody (Eds.), The SAGE handbook of remote sensing (pp. 357-367). London: SAGE. 
Appendix—A: Correlations of Variables by Income Group Countries

\begin{tabular}{|c|c|c|c|c|c|c|c|c|c|c|c|c|c|c|c|c|}
\hline \multirow[b]{2}{*}{ Region } & \multirow[b]{2}{*}{ Income group } & \multicolumn{3}{|c|}{ Rural Population, $\%$} & \multicolumn{3}{|c|}{ Agriculture Land, \% } & \multicolumn{3}{|c|}{ Active Labour Force, $\%$} & \multicolumn{3}{|c|}{$\begin{array}{c}\text { Agriculture value added in } \\
\text { GDP, } \% \\
\end{array}$} & \multicolumn{3}{|c|}{$\begin{array}{c}\mathrm{CO}_{2} \text { Emissions per Capita, } \\
\text { Metric Tonnes }\end{array}$} \\
\hline & & $\begin{array}{r}\text { Country } \\
(\text { No. }) \\
\end{array}$ & $\begin{array}{r}\text { Average } \\
(\%) \\
\end{array}$ & $\begin{array}{l}\text { Std. } \\
\text { Dev. }\end{array}$ & $\begin{array}{r}\text { Country } \\
(\text { No. }) \\
\end{array}$ & $\begin{array}{r}\text { Average } \\
(\%) \\
\end{array}$ & $\begin{array}{l}\text { Std. } \\
\text { Dev. }\end{array}$ & $\begin{array}{r}\text { Country } \\
(\text { No. }) \\
\end{array}$ & $\begin{array}{r}\text { Average } \\
(\%) \\
\end{array}$ & $\begin{array}{l}\text { Std. } \\
\text { Dev. }\end{array}$ & $\begin{array}{r}\text { Country } \\
(\text { No. }) \\
\end{array}$ & $\begin{array}{r}\text { Average } \\
(\%) \\
\end{array}$ & $\begin{array}{l}\text { Std. } \\
\text { Dev. }\end{array}$ & $\begin{array}{r}\text { Country } \\
(\text { No. }) \\
\end{array}$ & $\begin{array}{r}\text { Average } \\
(\%) \\
\end{array}$ & $\begin{array}{l}\text { Std. } \\
\text { Dev. }\end{array}$ \\
\hline East Asia \& & High income: nonOECD & 5 & 23.4 & 15.5 & 7 & 10.2 & 11.0 & 7 & 62.7 & 5.7 & 4 & 0.2 & 0.3 & 6 & 9.2 & 8.8 \\
\hline \multirow{4}{*}{ Pacific } & High income: OECD & 4 & 13.0 & 3.9 & 4 & 31.8 & 19.6 & 4 & 63.5 & 4.2 & 4 & 3.3 & 2.5 & 4 & 11.2 & 4.0 \\
\hline & Low income & 2 & 60.0 & 28.3 & 2 & 26.9 & 7.2 & 2 & 80.5 & 3.5 & 1 & 36.7 & & 2 & 1.7 & 1.9 \\
\hline & Lower middle income & 12 & 69.3 & 11.4 & 12 & 22.4 & 13.8 & 10 & 65.5 & 14.6 & 8 & 21.7 & 6.6 & 12 & 0.9 & 0.7 \\
\hline & Upper middle income & 10 & 38.9 & 19.5 & 10 & 42.6 & 22.0 & 6 & 63.8 & 6.7 & 8 & 13.8 & 6.9 & 8 & 5.2 & 3.5 \\
\hline \multicolumn{2}{|c|}{ East Asia \& Pacific Total } & 33 & 45.8 & 25.6 & 35 & 27.1 & 19.7 & 29 & 65.2 & 10.2 & 25 & 13.4 & 10.9 & 32 & 4.8 & 5.7 \\
\hline Europe \& & High income: nonOECD & 11 & 35.7 & 22.8 & 11 & 27.1 & 21.9 & 5 & 59.6 & 4.7 & 6 & 3.3 & 1.6 & 9 & 7.1 & 4.1 \\
\hline \multirow[t]{3}{*}{ Central Asia } & High income: OECD & 24 & 25.0 & 12.4 & 24 & 42.4 & 19.4 & 24 & 59.7 & 5.6 & 24 & 2.3 & 1.6 & 24 & 8.2 & 3.5 \\
\hline & Lower middle income & 7 & 53.1 & 15.5 & 7 & 56.3 & 15.9 & 7 & 60.6 & 8.8 & 7 & 17.3 & 6.6 & 7 & 2.4 & 2.0 \\
\hline & Upper middle income & 12 & 41.9 & 10.6 & 12 & 53.1 & 13.0 & 12 & 55.7 & 7.4 & 12 & 9.8 & 4.4 & 12 & 6.4 & 3.9 \\
\hline \multicolumn{2}{|c|}{ Europe \& Central Asia Total } & 54 & 34.6 & 17.8 & 54 & 43.4 & 20.4 & 48 & 58.8 & 6.6 & 49 & 6.4 & 6.4 & 52 & 6.8 & 4.0 \\
\hline Latin & High income: nonOECD & 13 & 33.1 & 32.6 & 13 & 23.6 & 22.7 & 8 & 63.5 & 9.3 & 11 & 3.1 & 3.4 & 11 & 10.2 & 10.6 \\
\hline America \& & High income: OECD & 1 & 11.0 & & 1 & 21.2 & & 1 & 62.0 & & 1 & 3.6 & & 1 & 4.6 & \\
\hline \multirow{3}{*}{ Caribbean } & Low income & 1 & 47.0 & & 1 & 66.4 & & 1 & 65.0 & & & & & 1 & 0.2 & \\
\hline & Lower middle income & 6 & 46.7 & 14.1 & 6 & 37.5 & 21.5 & 6 & 64.7 & 4.4 & 6 & 15.3 & 3.7 & 6 & 1.3 & 0.6 \\
\hline & Upper middle income & 17 & 37.5 & 17.5 & 17 & 33.0 & 16.3 & 15 & 65.5 & 5.3 & 17 & 7.8 & 4.9 & 17 & 2.3 & 0.8 \\
\hline \multicolumn{2}{|c|}{ Latin America \& Caribbean Total } & 38 & 37.0 & 23.4 & 38 & 31.0 & 20.2 & 31 & 64.7 & 6.1 & 35 & 7.5 & 5.9 & 36 & 4.6 & 6.9 \\
\hline Middle East & High income: nonOECD & 7 & 11.0 & 8.8 & 7 & 21.1 & 28.0 & 7 & 67.1 & 13.3 & 4 & 1.1 & 0.7 & 7 & 22.1 & 11.7 \\
\hline$\&$ North & High income: OECD & 1 & 8.0 & & 1 & 23.9 & & 1 & 57.0 & & & & & 1 & 9.0 & \\
\hline \multirow{2}{*}{ Africa } & Lower middle income & 6 & 43.3 & 17.4 & 6 & 51.3 & 27.3 & 6 & 47.2 & 3.9 & 3 & 12.3 & 4.7 & 6 & 1.5 & 1.0 \\
\hline & Upper middle income & 7 & 25.4 & 8.1 & 7 & 30.6 & 23.8 & 7 & 45.6 & 3.9 & 4 & 6.2 & 2.9 & 7 & 4.6 & 1.8 \\
\hline \multicolumn{2}{|c|}{ Middle East \& North Africa Total } & 21 & 24.9 & 17.4 & 21 & 33.0 & 27.4 & 21 & 53.8 & 12.7 & 11 & 6.0 & 5.4 & 21 & 9.8 & $\mathbf{1 1 . 2}$ \\
\hline North & High income: nonOECD & & & & 1 & 6.0 & & & & & 1 & 0.8 & & 1 & 6.1 & \\
\hline America & High income: OECD & 2 & 19.0 & 0.0 & 2 & 25.6 & 26.4 & 2 & 64.5 & 2.1 & 1 & 1.4 & & 2 & 15.6 & 2.1 \\
\hline \multicolumn{2}{|c|}{ North America Total } & 2 & 19.0 & 0.0 & 3 & 19.0 & 21.8 & 2 & 64.5 & 2.1 & 2 & 1.1 & 0.4 & 3 & 12.4 & 5.6 \\
\hline \multirow[t]{3}{*}{ South Asia } & Low income & 2 & 79.0 & 5.7 & 2 & 43.5 & 20.7 & 2 & 65.5 & 24.7 & 2 & 31.4 & 9.8 & 2 & 0.3 & 0.1 \\
\hline & Lower middle income & 5 & 69.4 & 7.6 & 5 & 46.8 & 21.5 & 5 & 61.4 & 9.2 & 5 & 18.3 & 5.0 & 5 & 0.9 & 0.5 \\
\hline & Upper middle income & 1 & 59.0 & & 1 & 26.3 & & 1 & 66.0 & & 1 & 4.1 & & 1 & 3.3 & \\
\hline \multicolumn{2}{|c|}{ South Asia Total } & 8 & 70.5 & 8.8 & 8 & 43.4 & 19.4 & 8 & 63.0 & 11.9 & 8 & 19.8 & 10.2 & 8 & 1.1 & 1.0 \\
\hline Sub-Saharan & High income: nonOECD & 2 & 54.0 & 9.9 & 2 & 6.6 & 4.9 & 1 & 87.0 & & 1 & 2.2 & & 2 & 7.9 & 1.5 \\
\hline \multirow[t]{3}{*}{ Africa } & Low income & 26 & 69.1 & 11.5 & 25 & 51.3 & 19.7 & 25 & 76.2 & 9.7 & 20 & 35.7 & 11.6 & 25 & 0.2 & 0.1 \\
\hline & Lower middle income & 14 & 55.1 & 14.9 & 14 & 49.4 & 19.9 & 14 & 65.2 & 8.2 & 14 & 17.5 & 8.8 & 14 & 0.5 & 0.3 \\
\hline & Upper middle income & 6 & 45.2 & 17.8 & 6 & 47.2 & 18.9 & 6 & 62.8 & 9.2 & 6 & 5.1 & 3.2 & 6 & 3.1 & 3.1 \\
\hline \multirow{2}{*}{\multicolumn{2}{|c|}{$\begin{array}{l}\text { Sub-Saharan Afri } \\
\text { Grand Total }\end{array}$}} & 48 & 61.4 & 15.8 & 47 & 48.3 & 20.9 & 46 & 71.3 & 10.9 & 41 & 24.2 & 15.5 & 47 & 1.0 & 2.1 \\
\hline & & 204 & 43.4 & 23.5 & 206 & 38.1 & 22.5 & 185 & 63.6 & 10.8 & 171 & 12.4 & 12.4 & 199 & 4.9 & 6.3 \\
\hline
\end{tabular}

Note: Source of data is the World Bank (2015), accessed and analyzed for the years from 1991 to 2011; http://data.worldbank.org/indicator

Figure A-1. Summary matrix of rural population, agriculture lands, active labour population, and agriculture value added in $\mathrm{GDP}$ in percent; and $\mathrm{CO}_{2}$ emissions per capita in metric tonnes by region and income group countries in 2011. 


\begin{tabular}{|c|c|c|c|c|c|c|c|c|c|c|c|c|c|c|c|c|}
\hline \multirow[b]{2}{*}{$\begin{array}{l}\text { Income } \\
\text { Group }\end{array}$} & \multirow[b]{2}{*}{ Region } & \multicolumn{3}{|c|}{ Rural Population, \% } & \multicolumn{3}{|c|}{ Agriculture Land, \% } & \multicolumn{3}{|c|}{ Active Labour Force, $\%$} & \multicolumn{3}{|c|}{$\begin{array}{c}\text { Agriculture Value added in } \\
\text { GDP, } \% \\
\end{array}$} & \multicolumn{3}{|c|}{$\begin{array}{c}\mathrm{CO}_{2} \text { Emissions per Capita, } \\
\text { Metric Tonnes }\end{array}$} \\
\hline & & $\begin{array}{r}\text { Country } \\
(\text { No. }) \\
\end{array}$ & $\begin{array}{r}\text { Average } \\
(\%) \\
\end{array}$ & $\begin{array}{l}\text { Std. } \\
\text { Dev. }\end{array}$ & $\begin{array}{r}\text { Country } \\
(\text { No. }) \\
\end{array}$ & $\begin{array}{r}\text { Average } \\
(\%) \\
\end{array}$ & $\begin{array}{l}\text { Std. } \\
\text { Dev. }\end{array}$ & $\begin{array}{r}\text { Country } \\
(\text { No. }) \\
\end{array}$ & $\begin{array}{r}\text { Average } \\
(\%) \\
\end{array}$ & $\begin{array}{l}\text { Std. } \\
\text { Dev. }\end{array}$ & $\begin{array}{r}\text { Country } \\
(\text { No. }) \\
\end{array}$ & $\begin{array}{r}\text { Average } \\
(\%) \\
\end{array}$ & $\begin{array}{l}\text { Std. } \\
\text { Dev. }\end{array}$ & $\begin{array}{r}\text { Country } \\
\text { (No.) } \\
\end{array}$ & $\begin{array}{r}\text { Average } \\
(\%) \\
\end{array}$ & $\begin{array}{l}\text { Std. } \\
\text { Dev. }\end{array}$ \\
\hline High income: & : East Asia \& Pacific & 5 & 23.4 & 15.5 & 7 & 10.2 & 11.0 & 7 & 62.7 & 5.7 & 4 & 0.2 & 0.3 & 6 & 9.2 & 8.8 \\
\hline \multirow{5}{*}{ nonOECD } & Europe \& Central Asia & 11 & 35.7 & 22.8 & 11 & 27.1 & 21.9 & 5 & 59.6 & 4.7 & 6 & 3.3 & 1.6 & 9 & 7.1 & 4.1 \\
\hline & Latin America \& Caribbea & 13 & 33.1 & 32.6 & 13 & 23.6 & 22.7 & 8 & 63.5 & 9.3 & 11 & 3.1 & 3.4 & 11 & 10.2 & 10.6 \\
\hline & Middle East \& North Afric & 7 & 11.0 & 8.8 & 7 & 21.1 & 28.0 & 7 & 67.1 & 13.3 & 4 & 1.1 & 0.7 & 7 & 22.1 & 11.7 \\
\hline & North America & & & & 1 & 6.0 & & & & & 1 & 0.8 & & 1 & 6.1 & \\
\hline & Sub-Saharan Africa & 2 & 54.0 & 9.9 & 2 & 6.6 & 4.9 & 1 & 87.0 & & 1 & 2.2 & & 2 & 7.9 & 1.5 \\
\hline \multirow{5}{*}{$\begin{array}{l}\text { High income } \\
\text { OECD }\end{array}$} & : East Asia \& Pacific & 4 & 13.0 & 3.9 & 4 & 31.8 & 19.6 & 4 & 63.5 & 4.2 & 4 & 3.3 & 2.5 & 4 & 11.2 & 4.0 \\
\hline & Europe \& Central Asia & 24 & 25.0 & 12.4 & 24 & 42.4 & 19.4 & 24 & 59.7 & 5.6 & 24 & 2.3 & 1.6 & 24 & 8.2 & 3.5 \\
\hline & Latin America \& Caribbea & 1 & 11.0 & & 1 & 21.2 & & 1 & 62.0 & & 1 & 3.6 & & 1 & 4.6 & \\
\hline & Middle East \& North Afric & 1 & 8.0 & & 1 & 23.9 & & 1 & 57.0 & & & & & 1 & 9.0 & \\
\hline & North America & 2 & 19.0 & 0.0 & 2 & 25.6 & 26.4 & 2 & 64.5 & 2.1 & 1 & 1.4 & & 2 & 15.6 & 2.1 \\
\hline \multirow{5}{*}{ Low income } & OECD Total & 32 & 22.1 & 12.0 & 32 & 38.7 & 19.6 & 32 & 60.5 & 5.3 & 30 & 2.4 & 1.7 & 32 & 8.9 & 3.9 \\
\hline & East Asia \& Pacific & 2 & 60.0 & 28.3 & 2 & 26.9 & 7.2 & 2 & 80.5 & 3.5 & 1 & 36.7 & & 2 & 1.7 & 1.9 \\
\hline & Latin America \& Caribbea & 1 & 47.0 & & 1 & 66.4 & & 1 & 65.0 & & & & & 1 & 0.2 & \\
\hline & South Asia & 2 & 79.0 & 5.7 & 2 & 43.5 & 20.7 & 2 & 65.5 & 24.7 & 2 & 31.4 & 9.8 & 2 & 0.3 & 0.1 \\
\hline & Sub-Saharan Africa & 26 & 69.1 & 11.5 & 25 & 51.3 & 19.7 & 25 & 76.2 & 9.7 & 20 & 35.7 & 11.6 & 25 & 0.2 & 0.1 \\
\hline Lower & East Asia \& Pacific & 12 & 69.3 & 11.4 & 12 & 22.4 & 13.8 & 10 & 65.5 & 14.6 & 8 & 21.7 & 6.6 & 12 & 0.9 & 0.7 \\
\hline middle & Europe \& Central Asia & 7 & 53.1 & 15.5 & 7 & 56.3 & 15.9 & 7 & 60.6 & 8.8 & 7 & 17.3 & 6.6 & 7 & 2.4 & 2.0 \\
\hline \multirow[t]{4}{*}{ income } & Latin America \& Caribbea & 6 & 46.7 & 14.1 & 6 & 37.5 & 21.5 & 6 & 64.7 & 4.4 & 6 & 15.3 & 3.7 & 6 & 1.3 & 0.6 \\
\hline & Middle East \& North Afric & 6 & 43.3 & 17.4 & 6 & 51.3 & 27.3 & 6 & 47.2 & 3.9 & 3 & 12.3 & 4.7 & 6 & 1.5 & 1.0 \\
\hline & South Asia & 5 & 69.4 & 7.6 & 5 & 46.8 & 21.5 & 5 & 61.4 & 9.2 & 5 & 18.3 & 5.0 & 5 & 0.9 & 0.5 \\
\hline & Sub-Saharan Africa & 14 & 55.1 & 14.9 & 14 & 49.4 & 19.9 & 14 & 65.2 & 8.2 & 14 & 17.5 & 8.8 & 14 & 0.5 & 0.3 \\
\hline \multicolumn{2}{|c|}{ Lower middle income Total } & $\mathbf{5 0}$ & $\mathbf{5 7 . 2}$ & 16.3 & $\mathbf{5 0}$ & 42.4 & 22.2 & 48 & 61.9 & 10.7 & 43 & 17.6 & 7.0 & $\mathbf{5 0}$ & 1.1 & 1.1 \\
\hline Upper & East Asia \& Pacific & 10 & 38.9 & 19.5 & 10 & 42.6 & 22.0 & 6 & 63.8 & 6.7 & 8 & 13.8 & 6.9 & 8 & 5.2 & 3.5 \\
\hline middle & Europe \& Central Asia & 12 & 41.9 & 10.6 & 12 & 53.1 & 13.0 & 12 & 55.7 & 7.4 & 12 & 9.8 & 4.4 & 12 & 6.4 & 3.9 \\
\hline \multirow[t]{4}{*}{ income } & Latin America \& Caribbea & 17 & 37.5 & 17.5 & 17 & 33.0 & 16.3 & 15 & 65.5 & 5.3 & 17 & 7.8 & 4.9 & 17 & 2.3 & 0.8 \\
\hline & Middle East \& North Afric & 7 & 25.4 & 8.1 & 7 & 30.6 & 23.8 & 7 & 45.6 & 3.9 & 4 & 6.2 & 2.9 & 7 & 4.6 & 1.8 \\
\hline & South Asia & 1 & 59.0 & & 1 & 26.3 & & 1 & 66.0 & & 1 & 4.1 & & 1 & 3.3 & \\
\hline & Sub-Saharan Africa & 6 & 45.2 & 17.8 & 6 & 47.2 & 18.9 & 6 & 62.8 & 9.2 & 6 & 5.1 & 3.2 & 6 & 3.1 & 3.1 \\
\hline \multirow{2}{*}{\multicolumn{2}{|c|}{$\frac{\text { Upper middle in }}{\text { Grand Total }}$}} & 53 & 38.4 & 16.2 & 53 & 40.5 & 19.5 & 47 & 59.5 & 9.4 & 48 & 8.7 & 5.4 & 51 & 4.1 & 3.1 \\
\hline & & 204 & 43.4 & 23.5 & 206 & 38.1 & 22.5 & 185 & 63.6 & 10.8 & 171 & 12.4 & 12.4 & 199 & 4.9 & 6.3 \\
\hline
\end{tabular}

Note: Source of data is the World Bank (2015), accessed and analyzed for the years from 1991 to 2011 ; http://data.worldbank.org/indicator

Figure A-2. Summary matrix of rural population, agriculture lands, active labour population, and agriculture value added in $\mathrm{GDP}_{\text {in }}$ percent; and $\mathrm{CO}_{2}$ emissions per capita in metric tonnes by income group and region in 2011 . 


\begin{tabular}{|c|c|c|c|c|c|c|c|c|c|c|c|c|c|c|c|c|c|c|c|c|c|c|c|}
\hline Variables & $\begin{array}{c}\text { Total } \\
\text { Population } P_{C}\end{array}$ & $\begin{array}{c}\text { Rural } \\
\text { pulation }\end{array}$ & $\begin{array}{r}\text { Rural } \\
\text { Population, } \\
\%\end{array}$ & $\begin{array}{l}\begin{array}{l}\text { Agriculture } \\
\text { Value in } \\
G D P, \%\end{array} \\
G D\end{array}$ & $\begin{array}{c}\text { GNI per } \\
\text { Capitas } \\
\text { USs }\end{array}$ & $\begin{array}{c}G D P \\
\text { per } \\
\text { Capita, } \\
\text { USS } \\
\end{array}$ & $\begin{array}{r}\text { Net } \\
\text { Development } \\
\text { Assistance, } \\
\text { USS } \\
\end{array}$ & $\begin{array}{r}\text { Labour } \\
\text { Force of } \\
\text { Population, } \\
15+\text { Age } \\
\end{array}$ & $\begin{array}{c}\text { Labour } \\
\text { Force, } \\
\%\end{array}$ & $\begin{array}{r}\text { Arable } \\
\text { Land } \\
\text { per } \\
\text { Capita } \\
\end{array}$ & $\begin{array}{r}\text { Arable } \\
\text { Land of } \\
\text { Total } \\
\text { Land } \\
\text { Area, \% } \\
\end{array}$ & $\begin{array}{c}\text { Agriculture } \\
\text { Land of } \\
\text { Total Land } \\
\text { Area, } \% \\
\end{array}$ & $\begin{array}{c}\text { Improved } \\
\text { Rural } \\
\text { Wcter } \\
\text { Pcess } \\
\text { Population, } \\
\% \\
\end{array}$ & $\begin{array}{r}\text { Improved } \\
\text { Sanitation } \\
\text { Population, } \\
\%\end{array}$ & $\begin{array}{r}\text { Electricity } \\
\text { Access } \\
\text { Population, } \\
\% \\
\%\end{array}$ & $\begin{array}{c}\text { Permanent } \\
\text { Crops } \\
\text { Land, } \% \\
\end{array}$ & $\begin{array}{l}\begin{array}{c}\text { Fertilizer } \\
\text { per Ha, } \\
K g \\
K g\end{array} \\
\end{array}$ & $\begin{array}{r}\text { Cereals } \\
\text { per Ha, } \\
\mathrm{Kg} \\
\end{array}$ & $\begin{array}{c}\text { Crops } \\
\text { Production } \\
\text { Index }\end{array}$ & $\begin{array}{r}\text { Food } \\
\text { Production } \\
\text { Index } \\
\end{array}$ & $\begin{array}{r}\text { Livestock } \\
\text { Production } \\
\text { Index } \\
\end{array}$ & $\begin{array}{c}C O 2 \\
\text { Emissions, } \\
K T\end{array}$ & $\begin{array}{r}C O 2 \\
\text { Emissions, } \\
\text { Metric } \\
\text { Tonnes } \\
\end{array}$ \\
\hline $\bar{T}$ Total Population & 1.00 & & & & & & & & & & & & & & & & & & & & & & \\
\hline Rural Population & 0.97 & 1.00 & & & & & & & & & & & & & & & & & & & & & \\
\hline Rural Population, \% & 0.05 & 0.13 & 1.00 & & & & & & & & & & & & & & & & & & & & \\
\hline $\begin{array}{l}\text { Agriculture Value in } \\
G D P, \%\end{array}$ & 0.01 & 0.07 & 0.64 & 1.00 & & & & & & & & & & & & & & & & & & & \\
\hline GNI per Capita, USS & -0.05 & -0.06 & -0.01 & -0.07 & 1.00 & & & & & & & & & & & & & & & & & & \\
\hline GDP per Capita, USS & -0.05 & -0.09 & -0.47 & -0.53 & 0.05 & 1.00 & & & & & & & & & & & & & & & & & \\
\hline $\begin{array}{l}\text { Net Development } \\
\text { Assistance, USS }\end{array}$ & 0.14 & 0.19 & 0.19 & 0.24 & -0.11 & -0.30 & 1.00 & & & & & & & & & & & & & & & & \\
\hline $\begin{array}{l}\text { Labour Force of } \\
\text { Population, } 15+\text { Age }\end{array}$ & 0.98 & 0.92 & 0.04 & -0.01 & -0.07 & -0.04 & 0.07 & 1.00 & & & & & & & & & & & & & & & \\
\hline Labour Force, \% & 0.00 & 0.01 & 0.30 & 0.41 & 0.01 & -0.03 & -0.02 & 0.03 & 1.00 & & & & & & & & & & & & & & \\
\hline $\begin{array}{l}\text { Arable Land per } \\
\text { Capita }\end{array}$ & -0.01 & -0.03 & -0.05 & 0.06 & -0.08 & 0.03 & 0.00 & -0.02 & 0.02 & 1.00 & & & & & & & & & & & & & \\
\hline $\begin{array}{l}\text { Arable Land of Total } \\
\text { Land Area, } \%\end{array}$ & 0.17 & 0.20 & 0.14 & 0.09 & -0.05 & -0.03 & 0.18 & 0.13 & -0.06 & 0.17 & 1.00 & & & & & & & & & & & & \\
\hline $\begin{array}{l}\text { Agriculture Land of } \\
\text { Total Land Area, \% }\end{array}$ & 0.11 & 0.11 & 0.18 & $\overbrace{}^{0.21}$ & -0.01 & $\overbrace{}^{-0.22}$ & 0.10 & 0.09 & -0.06 & 0.23 & 0.56 & 1.00 & & & & & & & & & & & \\
\hline $\begin{array}{l}\text { Improved Rural Water } \\
\text { Access Population, } \%\end{array}$ & 0.02 & -0.01 & -0.48 & -0.64 & -0.08 & 0.47 & -0.32 & 0.04 & $\overbrace{}^{-0.33}$ & 0.01 & 0.15 & -0.18 & 1.00 & & & & & & & & & & \\
\hline $\begin{array}{l}\text { Improved Sanitation } \\
\text { Population, \% }\end{array}$ & -0.06 & -0.12 & -0.61 & -0.76 & -0.06 & 0.48 & -0.30 & -0.03 & -0.42 & 0.01 & 0.00 & -0.26 & 0.80 & 1.00 & & & & & & & & & \\
\hline $\begin{array}{l}\text { Electricity Access } \\
\text { Population, \% }\end{array}$ & 0.06 & 0.01 & $(-0.58$ & $(-0.72)$ & -0.05 & 0.39 & -0.22 & 0.08 & -0.47 & 0.05 & 0.03 & -0.16 & 0.72 & 0.86 & 1.00 & & & & & & & & \\
\hline $\begin{array}{l}\text { Permanent Crops } \\
\text { Land, \% }\end{array}$ & -0.04 & -0.02 & 0.10 & 0.21 & -0.01 & -0.20 & -0.13 & -0.02 & -0.08 & -0.25 & 0.10 & 0.20 & 0.10 & -0.06 & -0.07 & 1.00 & & & & & & & \\
\hline Fertilizer per $\mathrm{Ha}, \mathrm{Kg}$ & 0.00 & -0.01 & -0.28 & -0.24 & 0.01 & 0.36 & -0.09 & 0.00 & 0.14 & -0.15 & -0.16 & -0.23 & 0.15 & 0.17 & 0.14 & -0.04 & 1.00 & & & & & & \\
\hline Cereals per $\mathrm{Ha}, \mathrm{Kg}$ & 0.02 & 0.00 & -0.23 & -0.23 & -0.07 & 0.26 & -0.11 & 0.03 & 0.06 & -0.10 & -0.03 & -0.17 & 0.26 & 0.27 & 0.22 & -0.08 & 0.12 & 1.00 & & & & & \\
\hline $\begin{array}{l}\text { Crops Production } \\
\text { Index }\end{array}$ & 0.08 & 0.10 & 0.12 & 0.35 & -0.06 & -0.20 & 0.08 & 0.07 & 0.24 & 0.20 & -0.01 & 0.15 & -0.41 & -0.30 & -0.23 & -0.11 & -0.02 & -0.22 & 1.00 & & & & \\
\hline $\begin{array}{l}\text { Food Production } \\
\text { Index }\end{array}$ & 0.09 & 0.11 & 0.17 & 0.41 & -0.03 & -0.23 & 0.12 & 0.07 & 0.32 & 0.10 & -0.04 & 0.10 & -0.43 & -0.34 & -0.31 & -0.12 & 0.05 & -0.24 & 0.77 & 1.00 & & & \\
\hline $\begin{array}{l}\text { Livestock Production } \\
\text { Index }\end{array}$ & 0.05 & 0.08 & 0.13 & 0.30 & -0.05 & -0.20 & 0.09 & 0.04 & 0.26 & -0.13 & -0.10 & 0.01 & -0.28 & -0.22 & -0.23 & -0.02 & 0.13 & 0.04 & 0.26 & 0.66 & 1.00 & & \\
\hline CO2 Emissions, $K T$ & 0.81 & 0.66 & -0.08 & -0.10 & 0.02 & 0.05 & -0.06 & 0.88 & -0.01 & 0.07 & 0.04 & 0.06 & 0.10 & 0.07 & 0.14 & -0.07 & 0.01 & 0.07 & 0.01 & 0.02 & 0.00 & 1.00 & \\
\hline $\begin{array}{l}\text { CO2 Emissions, } \\
\text { Metric Tonnes }\end{array}$ & -0.01 & -0.05 & -0.43 & -0.53 & 0.06 & 0.51 & -0.22 & 0.01 & -0.05 & 0.07 & -0.15 & -0.28 & 0.44 & 0.52 & 0.42 & -0.20 & 0.50 & 0.30 & -0.20 & -0.09 & 0.05 & 0.14 & 1.00 \\
\hline
\end{tabular}

Note: Source of data is the World Bank (2015), retrieved and analyzed for the years from 1991 to 2011 from http://data.worldbank.org/indicator

Figure A-3. Correlations among the variables for all countries, 1991-2011. 


\begin{tabular}{|c|c|c|c|c|c|c|c|c|c|c|c|c|c|c|c|c|c|c|c|c|c|c|c|}
\hline Variables & $\begin{array}{c}\begin{array}{c}\text { Total } \\
\text { Population } 1\end{array} \\
\end{array}$ & $\begin{array}{r}\text { Rural } \\
\text { opulation }\end{array}$ & $\begin{array}{r}\text { Rural } \\
\text { Population, } \\
\%\end{array}$ & $\begin{array}{r}\text { Agriculture } \\
\text { Value in } \\
G D P, \% \\
\end{array}$ & $\begin{array}{r}G N I \\
\text { per } \\
\text { Capita, } \\
\text { USS } \\
\end{array}$ & $\begin{array}{r}G D P \\
\text { per } \\
\text { Capita, } \\
\text { USS } \\
\end{array}$ & $\begin{array}{r}\text { Net } \\
\text { Development } \\
\text { Assistance, } \\
\text { USS } \\
\end{array}$ & $\begin{array}{c}\text { Labour } \\
\text { Force of } \\
\text { Population, } \\
15+\text { Age } \\
\end{array}$ & $\begin{array}{c}\text { Labour } \\
\text { Force, } \\
\% \\
\end{array}$ & $\begin{array}{r}\text { Arable } \\
\text { Land } \\
\text { per } \\
\text { Capita } \\
\end{array}$ & $\begin{array}{r}\text { Arable } \\
\text { Land of } \\
\text { Total } \\
\text { Land } \\
\text { Area, \% } \\
\end{array}$ & $\begin{array}{l}\text { Agriculture } \\
\text { Land of } \\
\text { Total Land } \\
\text { Area, } \% \\
\end{array}$ & $\begin{array}{r}\text { Improved } \\
\text { Rural Water } \\
\text { Access } \\
\text { Population, } \\
\% \\
\end{array}$ & $\begin{array}{r}\text { Improved } \\
\text { Sanitation } \\
\text { Population, } \\
\% \\
\end{array}$ & $\begin{array}{r}\text { Electricity } \\
\text { Access } \\
\text { Population, } \\
\% \\
\end{array}$ & $\begin{array}{r}\text { Permanent } \\
\text { Crops } \\
\text { Land, \% } \\
\end{array}$ & $\begin{array}{c}\text { Fertilizer } \\
\text { per Ha, } \\
\mathrm{Kg} \\
\end{array}$ & $\begin{array}{r}\text { Cereals } \\
\text { per Ha, } \\
\quad \mathrm{Kg} \\
\end{array}$ & $\begin{array}{c}\text { Crops } \\
\text { Production } \\
\text { Index } \\
\end{array}$ & $\begin{array}{c}\text { Food } \\
\text { Production } \\
\text { Index } \\
\end{array}$ & $\begin{array}{r}\text { Livestock } \\
\text { Production } \\
\text { Index } \\
\end{array}$ & $\begin{array}{r}C O 2 \\
\text { Emissions, } \\
K T \\
\end{array}$ & $\begin{array}{r}\mathrm{CO} 2 \\
\text { Emissions, } \\
\text { Metric } \\
\text { Tonnes } \\
\end{array}$ \\
\hline Total Population & 1.00 & & & & & & & & & & & & & & & & & & & & & & \\
\hline Rural Population & 0.96 & 1.00 & & & & & & & & & & & & & & & & & & & & & \\
\hline Rural Population, \% & -0.10 & 0.05 & 1.00 & & & & & & & & & & & & & & & & & & & & \\
\hline $\begin{array}{l}\text { Agriculture Value in } \\
\text { GDP, \% }\end{array}$ & -0.25 & -0.23 & 0.00 & 1.00 & & & & & & & & & & & & & & & & & & & \\
\hline GNI per Capita, USS & 0.00 & 0.01 & 0.06 & 0.03 & 1.00 & & & & & & & & & & & & & & & & & & \\
\hline GDP per Capita, USS & -0.02 & -0.07 & -0.38 & -0.47 & -0.08 & 1.00 & & & & & & & & & & & & & & & & & \\
\hline $\begin{array}{l}\text { Net Development } \\
\text { Assistance, USS }\end{array}$ & & & & & & & 1.00 & & & & & & & & & & & & & & & & \\
\hline $\begin{array}{l}\text { Labour Force of } \\
\text { Population, } 15+\text { Age }\end{array}$ & 1.00 & 0.95 & -0.11 & -0.25 & 0.00 & -0.01 & & 1.00 & & & & & & & & & & & & & & & \\
\hline Labour Force, \% & -0.03 & -0.11 & -0.29 & 0.27 & 0.04 & 0.33 & & -0.01 & 1.00 & & & & & & & & & & & & & & \\
\hline $\begin{array}{l}\text { Arable Land per } \\
\text { Capita }\end{array}$ & 0.04 & 0.03 & -0.12 & 0.13 & 0.01 & 0.09 & & 0.05 & 0.27 & 1.00 & & & & & & & & & & & & & \\
\hline $\begin{array}{l}\text { Arable Land of Total } \\
\text { Land Area, \% }\end{array}$ & 0.04 & 0.12 & 0.16 & -0.23 & -0.25 & -0.18 & & 0.02 & -0.49 & -0.12 & 1.00 & & & & & & & & & & & & \\
\hline $\begin{array}{l}\text { Agriculture Land of } \\
\text { Total Land Area, \% }\end{array}$ & 0.06 & 0.15 & 0.16 & -0.15 & -0.29 & -0.10 & & 0.05 & -0.33 & 0.01 & 0.66 & 1.00 & & & & & & & & & & & \\
\hline $\begin{array}{l}\text { Improved Rural Water } \\
\text { Access Population, \% }\end{array}$ & -0.09 & -0.09 & 0.04 & -0.10 & -0.17 & 0.32 & & -0.09 & -0.03 & 0.13 & 0.17 & 0.23 & 1.00 & & & & & & & & & & \\
\hline $\begin{array}{l}\text { Improved Sanitation } \\
\text { Population, \% }\end{array}$ & 0.21 & 0.15 & -0.35 & -0.10 & 0.00 & 0.05 & & 0.21 & 0.07 & 0.10 & -0.02 & -0.20 & 0.13 & 1.00 & & & & & & & & & \\
\hline $\begin{array}{l}\text { Electricity Access } \\
\text { Population, \% }\end{array}$ & 0.05 & 0.08 & 0.17 & -0.13 & 0.08 & 0.22 & & 0.05 & -0.05 & 0.10 & 0.23 & 0.16 & 0.63 & 0.07 & 1.00 & & & & & & & & \\
\hline $\begin{array}{l}\text { Permanent Crops } \\
\text { Land, \% }\end{array}$ & -0.02 & 0.06 & 0.17 & 0.12 & 0.09 & -0.31 & & -0.04 & -0.51 & -0.18 & 0.06 & 0.23 & 0.08 & 0.21 & 0.08 & 1.00 & & & & & & & \\
\hline Fertilizer per $\mathrm{Ha}, \mathrm{Kg}$ & -0.10 & -0.14 & -0.19 & 0.42 & 0.01 & -0.05 & & -0.10 & 0.22 & -0.26 & -0.30 & 0.01 & -0.16 & -0.34 & -0.19 & -0.14 & 1.00 & & & & & & \\
\hline Cereals per $\mathrm{Ha}, \mathrm{Kg}$ & 0.18 & 0.14 & -0.08 & -0.26 & -0.28 & 0.04 & & 0.17 & -0.06 & -0.51 & 0.16 & 0.32 & -0.18 & -0.11 & -0.15 & -0.20 & 0.33 & 1.00 & & & & & \\
\hline $\begin{array}{l}\text { Crops Production } \\
\text { Index }\end{array}$ & -0.03 & -0.05 & -0.02 & 0.04 & -0.05 & -0.16 & & -0.03 & 0.36 & 0.32 & -0.15 & 0.03 & -0.11 & 0.08 & -0.26 & -0.26 & 0.16 & -0.04 & 1.00 & & & & \\
\hline $\begin{array}{l}\text { Food Production } \\
\text { Index }\end{array}$ & 0.12 & 0.10 & -0.32 & 0.09 & -0.08 & 0.01 & & 0.12 & 0.54 & 0.19 & -0.23 & -0.08 & -0.19 & 0.01 & -0.29 & -0.23 & 0.12 & 0.03 & 0.73 & 1.00 & & & \\
\hline Livst Production Index & 0.13 & 0.12 & -0.40 & 0.07 & 0.06 & 0.03 & & 0.13 & 0.34 & -0.16 & -0.17 & -0.06 & -0.27 & -0.07 & -0.24 & -0.02 & 0.16 & 0.13 & 0.33 & 0.82 & 1.00 & & \\
\hline CO2 Emissions, KT & 0.97 & 0.93 & -0.09 & -0.19 & 0.05 & 0.02 & & 0.97 & 0.05 & 0.11 & -0.02 & 0.03 & -0.10 & 0.18 & 0.05 & -0.09 & -0.09 & 0.15 & -0.01 & 0.14 & 0.12 & 1.00 & \\
\hline $\begin{array}{l}\text { CO2 Emissions, } \\
\text { Metric Tonnes }\end{array}$ & 0.31 & 0.26 & -0.25 & -0.25 & 0.06 & 0.38 & & 0.32 & 0.08 & 0.45 & -0.09 & -0.06 & -0.02 & 0.03 & 0.20 & -0.30 & -0.12 & -0.24 & 0.07 & 0.14 & 0.02 & 0.40 & 1.00 \\
\hline
\end{tabular}

Note: Source of data is the World Bank (2015), accessed and analyzed for the years from 1991 to 2011; http//data.worldbank.org/indicator

Figure A-4. Correlations among the variables for high-income OECD countries, 1991-2011. 


\begin{tabular}{|c|c|c|c|c|c|c|c|c|c|c|c|c|c|c|c|c|c|c|c|c|c|c|c|}
\hline Variables & $\begin{array}{c}\text { Total } \\
\text { Population } P \\
\end{array}$ & $\begin{array}{r}\text { Rural } \\
\text { Oopulation }\end{array}$ & $\begin{array}{r}\text { Rural } \\
\text { Population, } \\
\%\end{array}$ & $\begin{array}{r}\text { Agriculture } \\
\text { Value in } \\
G D P, \% \\
\end{array}$ & $\begin{array}{r}\text { GNI per } \\
\text { Capita, } \\
\text { USS } \\
\end{array}$ & $\begin{array}{r}\text { GDP per } \\
\text { Capita, } \\
\text { USS } \\
\end{array}$ & $\begin{array}{r}\text { Net } \\
\text { Developpent } \\
\text { Assistance, } \\
\text { USS }\end{array}$ & $\begin{array}{c}\text { Labour } \\
\text { Force of } \\
\text { Population, } \\
15+\text { Agg }\end{array}$ & $\begin{array}{r}\text { Labour } \\
\text { Force, } \\
\%\end{array}$ & $\begin{array}{c}\text { Arable } \\
\text { Land } \\
\text { per } \\
\text { Capita } \\
\end{array}$ & $\begin{array}{r}\text { Arable } \\
\text { Land of } \\
\text { Total } \\
\text { Land } \\
\text { Area, } \% \\
\end{array}$ & $\begin{array}{l}\text { Agriculture } \\
\text { Land of } \\
\text { Total Land } \\
\text { Area, } \% \\
\end{array}$ & $\begin{array}{r}\text { Improved } \\
\text { Rural Water } \\
\text { Access } \\
\text { Population, } \\
\% \\
\end{array}$ & $\begin{array}{r}\text { Improved } \\
\text { Sanitation } \\
\text { Population, } \\
\% \\
\end{array}$ & $\begin{array}{c}\text { Electricity } \\
\text { Access } \\
\text { Population, } \\
\% \\
\end{array}$ & $\begin{array}{r}\text { Permanent } \\
\text { Crops } \\
\text { Land, \% } \\
\end{array}$ & $\begin{array}{r}\text { Fertilizer } \\
\text { per Ha, } \\
K g \\
\end{array}$ & $\begin{array}{r}\text { Cereals } \\
\text { per Ha, } \\
\quad \mathrm{Kg} \\
\end{array}$ & $\begin{array}{r}\text { Crops } \\
\text { Production } \\
\text { Index } \\
\end{array}$ & $\begin{array}{r}\text { Food } \\
\text { Production } \\
\text { Index }\end{array}$ & 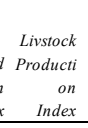 & 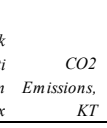 & $\begin{array}{r}\mathrm{CO} 2 \\
\text { Emissions, } \\
\text { Metric } \\
\text { Tonnes } \\
\end{array}$ \\
\hline Total Population & 1.00 & & & & & & & & & & & & & & & & & & & & & & \\
\hline Rural Population & 0.98 & 1.00 & & & & & & & & & & & & & & & & & & & & & \\
\hline Rural Population, \% & -0.11 & 0.00 & 1.00 & & & & & & & & & & & & & & & & & & & & \\
\hline $\begin{array}{l}\text { Agriculture Value in } \\
\text { GDP, } \%\end{array}$ & 0.29 & 0.23 & -0.07 & 1.00 & & & & & & & & & & & & & & & & & & & \\
\hline GNI per Capita, USS & 0.00 & -0.02 & -0.10 & -0.26 & 1.00 & & & & & & & & & & & & & & & & & & \\
\hline $\begin{array}{l}\text { Net Development } \\
\text { Assistance, USS }\end{array}$ & 0.95 & 0.91 & -0.61 & 0.39 & 0.02 & -0.14 & 1.00 & & & & & & & & & & & & & & & & \\
\hline $\begin{array}{l}\text { Labour Force of } \\
\text { Population, } 15+\text { Age }\end{array}$ & 1.00 & 0.98 & -0.04 & 0.26 & -0.08 & -0.23 & 0.93 & 1.00 & & & & & & & & & & & & & & & \\
\hline Labour Force, \% & -0.08 & -0.07 & 0.05 & -0.12 & -0.10 & 0.45 & -0.58 & -0.06 & 1.00 & & & & & & & & & & & & & & \\
\hline Arable Land per Capita & 0.61 & 0.55 & -0.01 & 0.73 & -0.18 & -0.28 & 0.76 & 0.59 & -0.13 & 1.00 & & & & & & & & & & & & & \\
\hline $\begin{array}{l}\text { Arable Land of Total } \\
\text { Land Area, } \%\end{array}$ & -0.05 & -0.02 & 0.32 & 0.32 & -0.10 & -0.04 & 0.12 & -0.01 & -0.28 & 0.41 & 1.00 & & & & & & & & & & & & \\
\hline $\begin{array}{l}\text { Agriculture Land of Total } \\
\text { Land Area, \% }\end{array}$ & 0.08 & 0.02 & 0.03 & 0.65 & 0.02 & -0.11 & 0.26 & 0.05 & -0.33 & 0.48 & 0.55 & 1.00 & & & & & & & & & & & \\
\hline $\begin{array}{l}\text { Improved Sanitation } \\
\text { Population, \% }\end{array}$ & -0.50 & -0.55 & -0.27 & -0.30 & 0.03 & 0.32 & 0.21 & -0.59 & -0.28 & -0.45 & -0.09 & 0.08 & 0.55 & 1.00 & & & & & & & & & \\
\hline $\begin{array}{l}\text { Electricity Access } \\
\text { Population, \% }\end{array}$ & 0.17 & 0.13 & -0.10 & 0.34 & 0.02 & 0.12 & 0.31 & 0.20 & -0.02 & 0.22 & 0.27 & 0.15 & 0.24 & 0.18 & 1.00 & & & & & & & & \\
\hline Permanent CropLand\% & -0.21 & -0.16 & 0.02 & -0.28 & -0.09 & -0.20 & -0.35 & -0.20 & -0.18 & -0.29 & -0.10 & -0.01 & 0.13 & 0.00 & -0.51 & 1.00 & & & & & & & \\
\hline Fertilizer per $\mathrm{Ha}, \mathrm{Kg}$ & -0.10 & -0.11 & -0.36 & -0.36 & -0.02 & 0.86 & 0.08 & -0.12 & 0.66 & -0.21 & -0.27 & -0.26 & 0.18 & 0.20 & 0.11 & -0.21 & 1.00 & & & & & & \\
\hline Cereals per $\mathrm{Ha}, \mathrm{Kg}$ & -0.05 & -0.06 & -0.15 & -0.22 & -0.16 & 0.21 & 0.56 & -0.03 & 0.40 & -0.16 & -0.22 & -0.20 & 0.17 & 0.18 & 0.12 & -0.14 & 0.04 & $\begin{array}{l}4 \\
4.00\end{array}$ & & & & & \\
\hline Crops Production Index & 0.12 & 0.08 & -0.38 & 0.39 & -0.03 & 0.12 & 0.24 & 0.10 & 0.02 & 0.31 & -0.04 & 0.20 & -0.19 & -0.11 & 0.18 & -0.17 & 0.13 & $3-0.43$ & 1.00 & & & & \\
\hline Food Production Index & 0.09 & 0.08 & -0.29 & 0.23 & 0.20 & 0.06 & 0.40 & 0.05 & 0.16 & 0.06 & -0.24 & -0.01 & -0.10 & -0.01 & 0.03 & -0.09 & 0.22 & $2-0.42$ & 0.66 & 1.00 & & & \\
\hline Lisst Production Index & 0.02 & 0.04 & -0.20 & -0.02 & 0.17 & 0.04 & 0.34 & 0.00 & 0.29 & -0.17 & -0.33 & -0.12 & 0.10 & 0.15 & -0.02 & 0.01 & 0.22 & $2 \quad 0.32$ & 0.10 & 0.74 & $\begin{array}{ll}4 & 1.00\end{array}$ & & \\
\hline CO2 Emissions, $K T$ & 0.97 & 0.98 & -0.09 & 0.19 & 0.03 & -0.16 & 0.88 & 0.97 & -0.10 & 0.51 & -0.07 & 0.09 & -0.05 & -0.57 & 0.14 & -0.25 & -0.07 & $7 \quad-0.01$ & 0.05 & 0.09 & $\begin{array}{l}9 \\
9\end{array}$ & 1.00 & \\
\hline $\begin{array}{l}\text { CO2 Emissions, Metric } \\
\text { Tonnes }\end{array}$ & -0.02 & 0.03 & -0.01 & -0.39 & 0.22 & 0.09 & -0.11 & -0.03 & 0.35 & -0.28 & -0.40 & -0.30 & 0.11 & 0.13 & -0.01 & -0.07 & 0.54 & $4 \quad 0.16$ & -0.14 & 0.35 & $5 \quad 0.53$ & 0.10 & 1.00 \\
\hline
\end{tabular}

Note: Source of data is the World Bank (2015), retrieved and analyzed for the years from 1991 to 2011; http//data.worldbank.org/indicator

Figure A-5. Correlations among the variables for high-income non-OECD countries, 1991-2011. 


\begin{tabular}{|c|c|c|c|c|c|c|c|c|c|c|c|c|c|c|c|c|c|c|c|c|c|c|c|}
\hline Variables & $\begin{array}{r}\text { Total } \\
\text { Population } \\
\end{array}$ & $\begin{array}{c}\text { Rural } I \\
\text { Population }\end{array}$ & $\begin{array}{r}\text { Rural } \\
\text { Population, } \\
\% \\
\end{array}$ & $\begin{array}{c}\text { Agriculture } \\
\text { Value in } \\
G D P, \%\end{array}$ & $\begin{array}{r}\text { GNI per } \\
\text { Capita, } \\
\text { USS } \\
\end{array}$ & $\begin{array}{r}G D P \\
\text { per } \\
\text { Capita, } \\
\text { USS } \\
\end{array}$ & $\begin{array}{r}\text { Net } \\
\text { Development } \\
\text { Assistance, } \\
\text { USS } \\
\end{array}$ & $\begin{array}{r}\text { Labour } \\
\text { Force of } \\
\text { Population, } \\
15+\text { Age } \\
\end{array}$ & $\begin{array}{r}\text { Labour } \\
\text { Force, } \\
\% \\
\end{array}$ & $\begin{array}{r}\text { Arable } \\
\text { Land } \\
\text { per } \\
\text { Capita } \\
\end{array}$ & $\begin{array}{r}\text { Arable } \\
\text { Land of } \\
\text { Total } \\
\text { Land } \\
\text { Area, \% } \\
\end{array}$ & $\begin{array}{r}\text { Agriculture } \\
\text { Land of } \\
\text { Total Land } \\
\text { Area, \% }\end{array}$ & $\begin{array}{r}\text { Improved } \\
\text { Rural Water } \\
\text { Access } \\
\text { Population, } \\
\% \\
\end{array}$ & $\begin{array}{r}\text { Improved } \\
\text { Sanitation } \\
\text { Population, } \\
\% \\
\end{array}$ & $\begin{array}{r}\text { Electricity } \\
\text { Access } \\
\text { Population, } \\
\%\end{array}$ & $\begin{array}{r}\text { Permanent } \\
\text { Crops } \\
\text { Land, \% } \\
\end{array}$ & $\begin{array}{r}\text { Ferilizer } \\
\text { per Ha, } \\
K g \\
\end{array}$ & $\begin{array}{c}\text { Cereals } \\
\text { per Ha, }, \quad P, \\
K \\
\end{array}$ & $\begin{array}{r}\text { Crops } \\
\text { Production } \\
\text { Index } \\
\end{array}$ & $\begin{array}{c}\text { Food } \\
\text { Production } \\
\text { Index }\end{array}$ & $\begin{array}{r}\text { Livestock } \\
\text { Production } \\
\text { Index }\end{array}$ & $\begin{array}{r}\mathrm{CO} 2 \\
\text { Emissions, } \\
\mathrm{KT} \\
\end{array}$ & $\begin{array}{r}\mathrm{CO} 2 \\
\text { Emissions, } \\
\text { Metric } \\
\text { Tonnes } \\
\end{array}$ \\
\hline Total Population & 1.00 & & & & & & & & & & & & & & & & & & & & & & \\
\hline Rural Population & 0.98 & 1.00 & & & & & & & & & & & & & & & & & & & & & \\
\hline Rural Population, \% & 0.23 & 0.36 & 1.00 & & & & & & & & & & & & & & & & & & & & \\
\hline $\begin{array}{l}\text { Agriculture Value in } \\
\text { GDP, \% }\end{array}$ & -0.16 & -0.10 & -0.01 & 1.00 & & & & & & & & & & & & & & & & & & & \\
\hline GNI per Capita, USS & -0.18 & -0.20 & -0.07 & -0.28 & 1.00 & & & & & & & & & & & & & & & & & & \\
\hline GDP per Capita, USS & -0.21 & -0.20 & 0.08 & 0.04 & 0.15 & 1.00 & & & & & & & & & & & & & & & & & \\
\hline $\begin{array}{l}\text { Net Development } \\
\text { Assistance, USS }\end{array}$ & 0.68 & 0.64 & 0.13 & -0.32 & -0.25 & -0.10 & 1.00 & & & & & & & & & & & & & & & & \\
\hline $\begin{array}{l}\text { Labour Force of } \\
\text { Population, 15+ Age }\end{array}$ & 0.98 & 0.96 & 0.23 & -0.13 & -0.14 & -0.20 & 0.55 & 1.00 & & & & & & & & & & & & & & & \\
\hline Labour Force, \% & 0.21 & 0.23 & 0.25 & -0.18 & 0.12 & -0.10 & -0.27 & 0.34 & 1.00 & & & & & & & & & & & & & & \\
\hline Arable Land per Capita & -0.12 & -0.08 & 0.18 & 0.08 & -0.15 & 0.09 & -0.10 & -0.17 & -0.09 & 1.00 & & & & & & & & & & & & & \\
\hline $\begin{array}{l}\text { Arable Land of Total } \\
\text { Land Area, \% }\end{array}$ & -0.24 & -0.19 & 0.05 & -0.03 & 0.02 & 0.00 & -0.21 & -0.20 & 0.12 & -0.16 & 1.00 & & & & & & & & & & & & \\
\hline $\begin{array}{l}\text { Agriculture Land of } \\
\text { Total Land Area, \% }\end{array}$ & -0.33 & -0.27 & 0.20 & -0.16 & 0.36 & -0.07 & -0.17 & -0.34 & -0.03 & -0.27 & 0.51 & 1.00 & & & & & & & & & & & \\
\hline $\begin{array}{l}\text { Improved Rural Water } \\
\text { Access Population, \% }\end{array}$ & -0.26 & -0.24 & -0.01 & -0.08 & -0.06 & 0.09 & -0.40 & -0.17 & 0.22 & -0.13 & 0.52 & -0.04 & 1.00 & & & & & & & & & & \\
\hline $\begin{array}{l}\text { Improved Sanitation } \\
\text { Population, \% }\end{array}$ & -0.03 & -0.08 & -0.24 & -0.20 & -0.04 & -0.20 & -0.06 & 0.03 & 0.14 & -0.37 & 0.42 & -0.03 & 0.62 & 1.00 & & & & & & & & & \\
\hline $\begin{array}{l}\text { Electricity Access } \\
\text { Population, \% }\end{array}$ & -0.11 & -0.10 & -0.16 & -0.07 & 0.15 & 0.10 & -0.03 & -0.10 & -0.21 & -0.27 & 0.13 & 0.16 & 0.28 & 0.24 & 1.00 & & & & & & & & \\
\hline $\begin{array}{l}\text { Permanent Crops Land, } \\
\%\end{array}$ & -0.23 & -0.19 & 0.11 & 0.13 & 0.25 & 0.11 & -0.19 & -0.21 & -0.18 & -0.33 & 0.62 & 0.53 & 0.37 & 0.18 & 0.33 & 1.00 & & & & & & & \\
\hline Fertilizer per $\mathrm{Ha}, \mathrm{Kg}$ & 0.08 & 0.13 & 0.13 & 0.07 & -0.06 & 0.34 & -0.11 & 0.16 & 0.19 & -0.08 & -0.03 & -0.36 & 0.41 & 0.29 & 0.47 & -0.31 & 1.00 & & & & & & \\
\hline Cereals per $\mathrm{Ha}, \mathrm{Kg}$ & 0.16 & 0.16 & 0.04 & 0.09 & 0.12 & 0.03 & -0.07 & 0.27 & 0.31 & -0.35 & 0.20 & -0.12 & 0.42 & 0.47 & 0.10 & 0.07 & 0.24 & $\begin{array}{l}4.00 \\
+\end{array}$ & & & & & \\
\hline Crops Production Index & 0.17 & 0.22 & 0.32 & 0.11 & -0.14 & -0.02 & 0.07 & 0.20 & 0.27 & 0.22 & 0.12 & -0.04 & -0.13 & -0.13 & -0.11 & -0.09 & 0.16 & $5 \quad 0.34$ & 1.00 & & & & \\
\hline Food Production Index & 0.08 & 0.12 & 0.28 & 0.18 & -0.25 & -0.06 & 0.02 & 0.11 & 0.25 & 0.09 & 0.11 & 0.01 & -0.15 & -0.19 & -0.20 & -0.09 & 0.17 & 0.29 & 0.93 & 1.00 & & & \\
\hline $\begin{array}{l}\text { Livestock Production } \\
\text { Index }\end{array}$ & -0.05 & -0.02 & 0.11 & 0.33 & -0.25 & -0.35 & -0.09 & -0.05 & 0.04 & -0.12 & 0.15 & 0.11 & -0.03 & -0.21 & -0.29 & 0.00 & 0.26 & $\begin{array}{l}5 \\
5\end{array}$ & 0.33 & 0.55 & 1.00 & & \\
\hline CO2 Emissions, KT & 0.18 & 0.08 & -0.36 & -0.49 & -0.03 & 0.19 & 0.02 & 0.25 & 0.05 & -0.17 & -0.04 & -0.30 & 0.35 & 0.60 & 0.07 & -0.11 & 0.25 & 0.55 & -0.15 & -0.23 & -0.23 & 1.00 & \\
\hline $\begin{array}{l}\text { CO2 Emissions, Metric } \\
\text { Tonnes }\end{array}$ & 0.02 & -0.08 & -0.45 & -0.45 & 0.02 & 0.38 & -0.10 & 0.11 & 0.03 & -0.16 & 0.01 & -0.29 & 0.42 & 0.62 & 0.13 & -0.08 & 0.30 & 0.52 & -0.17 & -0.24 & -0.22 & 0.98 & 1.00 \\
\hline
\end{tabular}

Note: Source of data is the World Bank (2015), accessed and analyzed for the years from 1991 to 2011; http://data.worldbank.org/indicator

Figure A-6. Correlations among the variables for low-income countries, 1991-2011. 


\begin{tabular}{|c|c|c|c|c|c|c|c|c|c|c|c|c|c|c|c|c|c|c|c|c|c|c|c|}
\hline Variables & $\begin{array}{c}\text { Total } \\
\text { Population } P_{0} \\
\end{array}$ & $\begin{array}{r}\text { Rural } \\
\text { pulation }\end{array}$ & $\begin{array}{r}\begin{array}{r}\text { Rural } \\
\text { Population, } \\
\%\end{array} \\
\end{array}$ & $\begin{array}{r}\text { Agriculture } \\
\text { Value in } \\
G D P, \% \\
\end{array}$ & $\begin{array}{c}\text { GNI per } \\
\text { Capita, } \\
\text { USS } \\
\end{array}$ & $\begin{array}{c}\text { GDP per } \\
\text { Capita, } \\
\text { USs } \\
\end{array}$ & $\begin{array}{c}\text { Net } \\
\text { Development } \\
\text { Assistance, } \\
\text { USS } \\
\end{array}$ & $\begin{array}{r}\text { Labour } \\
\text { Forceof } \\
\text { Populatit } \\
\text { on, }{ }_{15+} \\
\text { Age } \\
\end{array}$ & $\begin{array}{r}\text { Labour } \\
\text { Force, } \\
\%\end{array}$ & $\begin{array}{c}\text { Arable } \\
\text { Land } \\
\text { per } \\
\text { Capita } \\
\end{array}$ & $\begin{array}{r}\text { Arable } \\
\text { Land of } \\
\text { Total } \\
\text { Land } \\
\text { Area, \% } \\
\end{array}$ & $\begin{array}{l}\text { Agriculture } \\
\text { Land of } \\
\text { Total Land } \\
\text { Area, } \%\end{array}$ & $\begin{array}{r}\text { Improved } \\
\text { Rural Water } \\
\text { Access } \\
\text { Population, } \\
\% \\
\end{array}$ & $\begin{array}{r}\text { Improved } \\
\text { Sanitation } \\
\text { Population, } \\
\%\end{array}$ & $\begin{array}{r}\text { Electricity } \\
\text { cccess } \\
\text { Population, } \\
\quad \% \\
\end{array}$ & $\begin{array}{r}\text { Permanent } \\
\text { Crops } \\
\text { Land, } \% \\
\end{array}$ & $\begin{array}{r}\text { t Fertilizer } \\
\text { per } \mathrm{Ha} \text {, } \\
\mathrm{Kg} \\
\end{array}$ & $\begin{array}{r}\text { Cereals } \\
\text { per Ha, } \\
\mathrm{Kg} \\
\end{array}$ & $\begin{array}{r}\text { Crops } \\
\text { Production } \\
\text { Index }\end{array}$ & $\begin{array}{r}\text { Food } \\
\text { Production } \\
\text { Index } \\
\end{array}$ & $\begin{array}{r}\text { Livestock } \\
\text { Production } \\
\text { Index }\end{array}$ & $\begin{array}{r}\mathrm{CO} 2 \\
\text { Emissions, } \\
K T \\
\end{array}$ & $\begin{array}{r}\text { CO2 } \\
\text { Emissions, } \\
\text { Metric } \\
\text { Tonnes } \\
\end{array}$ \\
\hline $\bar{T}$ Total Population & 1.00 & & & & & & & & & & & & & & & & & & & & & & \\
\hline Rural Population & 1.00 & 1.00 & & & & & & & & & & & & & & & & & & & & & \\
\hline Rural Population, \% & 0.11 & 0.13 & 1.00 & & & & & & & & & & & & & & & & & & & & \\
\hline $\begin{array}{l}\text { Agriculture Value in } \\
\text { GDP, \% }\end{array}$ & 0.04 & 0.05 & 0.34 & 1.00 & & & & & & & & & & & & & & & & & & & \\
\hline GNI per Capita, USS & -0.14 & -0.14 & -0.07 & -0.06 & 1.00 & & & & & & & & & & & & & & & & & & \\
\hline GDP per Capita, USS & -0.10 & -0.12 & -0.23 & -0.49 & 0.16 & 1.00 & & & & & & & & & & & & & & & & & \\
\hline $\begin{array}{l}\text { Net Development } \\
\text { Assistance, US\$ }\end{array}$ & 0.49 & 0.49 & 0.03 & 0.21 & -0.22 & -0.31 & 1.00 & & & & & & & & & & & & & & & & \\
\hline $\begin{array}{l}\text { Labour Force of } \\
\text { Population, } 15+\text { Age }\end{array}$ & 1.00 & 0.99 & 0.12 & 0.05 & -0.16 & -0.09 & 0.49 & 1.00 & & & & & & & & & & & & & & & \\
\hline Labour Force, \% & -0.07 & -0.07 & 0.12 & 0.13 & 0.00 & -0.14 & 0.00 & -0.04 & 1.00 & & & & & & & & & & & & & & \\
\hline Arable Land per Capita & -0.05 & -0.06 & -0.18 & -0.05 & -0.02 & 0.05 & 0.00 & -0.07 & 0.02 & 1.00 & & & & & & & & & & & & & \\
\hline $\begin{array}{l}\text { Arable Land of Total } \\
\text { Land Area, \% }\end{array}$ & 0.47 & 0.46 & -0.11 & -0.09 & -0.07 & -0.02 & 0.40 & 0.48 & -0.14 & 0.37 & 1.00 & & & & & & & & & & & & \\
\hline $\begin{array}{l}\text { Agriculture Land of } \\
\text { Total Land Area, \% }\end{array}$ & 0.14 & 0.14 & -0.33 & -0.10 & -0.14 & -0.14 & 0.20 & 0.13 & -0.26 & 0.19 & 0.57 & 1.00 & & & & & & & & & & & \\
\hline $\begin{array}{l}\text { Improved Rural Water } \\
\text { Access Population, \% }\end{array}$ & 0.14 & 0.13 & -0.07 & -0.15 & -0.18 & 0.40 & 0.01 & 0.15 & -0.15 & 0.00 & 0.27 & 0.02 & 1.00 & & & & & & & & & & \\
\hline $\begin{array}{l}\text { Improved Sanitation } \\
\text { Population, \% }\end{array}$ & -0.12 & -0.13 & -0.09 & -0.22 & -0.03 & 0.39 & -0.16 & -0.12 & -0.26 & 0.14 & 0.14 & -0.01 & 0.60 & 1.00 & & & & & & & & & \\
\hline $\begin{array}{l}\text { Electricity Access } \\
\text { Population, \% }\end{array}$ & 0.11 & 0.09 & -0.33 & -0.14 & -0.09 & 0.35 & 0.10 & 0.11 & -0.25 & 0.16 & 0.32 & 0.15 & 0.63 & 0.78 & 1.00 & & & & & & & & \\
\hline $\begin{array}{l}\text { Permanent Crops Land, } \\
\%\end{array}$ & -0.03 & -0.03 & -0.10 & 0.21 & -0.19 & 0.03 & -0.10 & 0.03 & -0.10 & -0.34 & 0.02 & 0.13 & 0.17 & -0.12 & 0.06 & 1.00 & & & & & & & \\
\hline Fertilizer per $\mathrm{Ha}, \mathrm{Kg}$ & 0.24 & 0.23 & 0.13 & -0.16 & -0.35 & 0.04 & 0.20 & 0.25 & -0.09 & -0.39 & 0.16 & -0.14 & 0.36 & 0.28 & 0.31 & 0.14 & 1.00 & & & & & & \\
\hline Cereals per $\mathrm{Ha}, \mathrm{Kg}$ & 0.15 & 0.14 & 0.24 & 0.02 & -0.15 & 0.04 & 0.07 & 0.18 & 0.11 & 0.01 & 0.16 & -0.29 & 0.28 & 0.39 & 0.38 & -0.08 & 0.75 & 1.00 & & & & & \\
\hline Crops Production Index & 0.16 & 0.16 & 0.00 & 0.13 & 0.10 & -0.19 & 0.05 & 0.18 & 0.41 & 0.21 & 0.10 & -0.08 & -0.24 & -0.09 & -0.18 & -0.20 & 0.11 & 0.23 & 1.00 & & & & \\
\hline Food Production Index & 0.14 & 0.14 & 0.09 & 0.15 & 0.01 & -0.32 & 0.10 & 0.15 & 0.39 & 0.12 & 0.01 & -0.05 & -0.35 & -0.13 & -0.18 & -0.20 & 0.09 & 0.24 & 0.90 & 1.00 & & & \\
\hline $\begin{array}{l}\text { Livestock Production } \\
\text { Index }\end{array}$ & 0.12 & 0.11 & 0.07 & 0.08 & -0.08 & -0.35 & 0.14 & 0.13 & 0.34 & -0.01 & -0.07 & -0.01 & -0.40 & -0.16 & -0.17 & -0.07 & 0.08 & 0.20 & 0.50 & 0.76 & 1.00 & & \\
\hline CO2 Emissions, $K T$ & 0.98 & 0.97 & 0.06 & -0.02 & -0.15 & -0.02 & 0.43 & 0.98 & -0.09 & 0.00 & 0.44 & 0.12 & 0.18 & -0.06 & 0.16 & -0.03 & 0.26 & 0.20 & 0.19 & 0.15 & 0.09 & 1.00 & \\
\hline $\begin{array}{l}\text { CO2 Emissions, Metric } \\
\text { Tonnes }\end{array}$ & 0.12 & 0.09 & -0.21 & -0.26 & -0.06 & 0.39 & -0.03 & 0.13 & -0.19 & 0.46 & 0.33 & 0.20 & 0.47 & 0.54 & 0.54 & -0.13 & 0.21 & 0.41 & 0.08 & -0.04 & -0.14 & 0.25 & 1.00 \\
\hline
\end{tabular}

Note: Source of data is the World Bank (2015), accessed and analyzed for the years from 1991 to 2011; http//data.worldbank.org/indicator

Figure A-7. Correlations among the variables for lower-middle income countries, 1991-2011. 


\begin{tabular}{|c|c|c|c|c|c|c|c|c|c|c|c|c|c|c|c|c|c|c|c|c|c|c|c|}
\hline Variables & $\begin{array}{r}\text { Total } \\
\text { Population }\end{array}$ & $\begin{array}{c}\text { Rural } \\
\text { Population }\end{array}$ & $\begin{array}{r}\text { Rural } \\
\text { Population, } \\
\%\end{array}$ & $\begin{array}{r}\text { Agriculture } \\
\text { Value in } \\
G D P, \%\end{array}$ & $\begin{array}{c}\text { GNI per } \\
\text { Gapita, } \\
\text { USS }\end{array}$ & $\begin{array}{r}G D P \\
\text { per } \\
\text { Capita, } \\
\text { USS } \\
\end{array}$ & $\begin{array}{r}\text { Net } \\
\text { Development } \\
\text { Assistance, } \\
\text { USS }\end{array}$ & $\begin{array}{c}\text { Labour } \\
\text { Force of } \\
\text { Population, } \\
15+\text { Age }\end{array}$ & $\begin{array}{r}\text { Labour } \\
\text { Force, } \\
\% \\
\end{array}$ & $\begin{array}{c}\text { Arable } \\
\text { Land per } \\
\text { Capita }\end{array}$ & $\begin{array}{c}\text { Arable } \\
\text { Land of } \\
\text { Total } \\
\text { Land } \\
\text { Area, \% } \\
\end{array}$ & $\begin{array}{l}\text { Agriculture } \\
\text { Land of } \\
\text { Total Land } \\
\text { Area, \% }\end{array}$ & 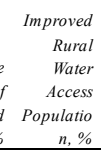 & $\begin{array}{c}\text { Improved } \\
\text { Sanitation } \\
\text { Population, } \\
\%\end{array}$ & $\begin{array}{r}\text { Electricity } \\
\text { Access } \\
\text { Population, } \\
\%\end{array}$ & $\begin{array}{r}\text { Permanent } \\
\text { Crops } \\
\text { Land, \% }\end{array}$ & $\begin{array}{r}\text { Fertilizer } \\
\text { per Ha, } \\
\mathrm{Kg}\end{array}$ & $\begin{array}{c}\text { Cereals } \\
\text { per Ha, } \\
K g\end{array}$ & $\begin{array}{r}\text { Crops } \\
\text { Production } \\
\text { Index }\end{array}$ & $\begin{array}{r}\text { Food } \\
\text { Production } \\
\text { Index }\end{array}$ & $\begin{array}{c}\text { Livestock } \\
\text { Production } \\
\text { Index }\end{array}$ & 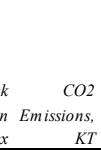 & 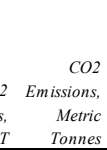 \\
\hline Total Population & 1.00 & & & & & & & & & & & & & & & & & & & & & & \\
\hline Rural Population & 0.99 & 1.00 & & & & & & & & & & & & & & & & & & & & & \\
\hline Rural Population, \% & 0.03 & 0.08 & 1.00 & & & & & & & & & & & & & & & & & & & & \\
\hline $\begin{array}{l}\text { Agriculture Value in } \\
\text { GDP, \% }\end{array}$ & -0.01 & 0.01 & 0.25 & 1.00 & & & & & & & & & & & & & & & & & & & \\
\hline GNI per Capita, USS & 0.11 & 0.12 & -0.21 & -0.07 & $\begin{array}{ll}7 & 1.00\end{array}$ & & & & & & & & & & & & & & & & & & \\
\hline GDP per Capita, USS & 0.01 & -0.05 & -0.33 & -0.56 & $5 \quad 0.21$ & 1.00 & & & & & & & & & & & & & & & & & \\
\hline $\begin{array}{l}\text { Net Development } \\
\text { Assistance, US\$ }\end{array}$ & -0.18 & -0.22 & -0.28 & -0.16 & $\begin{array}{l}5 \\
5\end{array} 0.14$ & 0.21 & 1.00 & & & & & & & & & & & & & & & & \\
\hline $\begin{array}{l}\text { Labour Force of } \\
\text { Population, } 15+\text { Age }\end{array}$ & 1.00 & 1.00 & 0.04 & 0.02 & 0.03 & -0.01 & -0.22 & 1.00 & & & & & & & & & & & & & & & \\
\hline Labour Force, \% & 0.19 & 0.19 & 0.30 & 0.04 & $4-0.16$ & 0.09 & -0.44 & 0.21 & 1.00 & & & & & & & & & & & & & & \\
\hline Arable Land per Capita & -0.06 & -0.07 & 0.03 & 0.16 & $5 \quad-0.18$ & 0.19 & 0.08 & -0.08 & 0.06 & 1.00 & & & & & & & & & & & & & \\
\hline $\begin{array}{l}\text { Arable Land of Total } \\
\text { Land Area, \% }\end{array}$ & -0.01 & 0.00 & 0.17 & 0.11 & 0.03 & 0.00 & 0.18 & -0.02 & -0.19 & 0.22 & 1.00 & & & & & & & & & & & & \\
\hline $\begin{array}{l}\text { Agriculture Land of } \\
\text { Total Land Area, \% }\end{array}$ & 0.11 & 0.11 & 0.09 & 0.15 & $5 \quad 0.02$ & -0.07 & 0.10 & 0.11 & 0.06 & 0.42 & 0.40 & 1.00 & & & & & & & & & & & \\
\hline $\begin{array}{l}\text { Improved Rural Water } \\
\text { Access Population, \% }\end{array}$ & -0.02 & -0.02 & 0.15 & 0.10 & 0.11 & 0.05 & -0.06 & 0.00 & -0.25 & 0.01 & 0.45 & -0.03 & 1.00 & & & & & & & & & & \\
\hline $\begin{array}{l}\text { Improved Sanitation } \\
\text { Population, \% }\end{array}$ & -0.10 & -0.11 & 0.08 & 0.11 & 0.07 & 0.00 & 0.07 & -0.11 & -0.28 & 0.09 & 0.33 & -0.17 & 0.60 & 1.00 & & & & & & & & & \\
\hline $\begin{array}{l}\text { Electricity Access } \\
\text { Population, \% }\end{array}$ & 0.11 & 0.09 & -0.09 & -0.13 & 30.09 & 0.20 & 0.18 & 0.09 & -0.29 & 0.17 & 0.31 & -0.03 & 0.25 & 0.54 & 1.00 & & & & & & & & \\
\hline $\begin{array}{l}\text { Permanent Crops Land, } \\
\%\end{array}$ & -0.09 & -0.08 & 0.08 & 0.48 & $3 \quad 0.12$ & -0.24 & -0.18 & -0.08 & 0.05 & -0.34 & 0.02 & 0.17 & 0.28 & 0.11 & -0.36 & 1.00 & & & & & & & \\
\hline Fertilizer per $\mathrm{Ha}, \mathrm{Kg}$ & 0.15 & 0.15 & -0.24 & -0.01 & 0.30 & 0.14 & -0.05 & 0.15 & -0.06 & -0.26 & -0.19 & -0.22 & 0.13 & 0.24 & 0.19 & 0.31 & 1.00 & & & & & & \\
\hline Cereals per $\mathrm{Ha}, \mathrm{Kg}$ & 0.09 & 0.09 & 0.11 & 0.03 & -0.07 & 0.00 & -0.08 & 0.09 & 0.13 & -0.11 & 0.16 & -0.07 & 0.21 & 0.28 & -0.01 & 0.06 & 0.16 & $6 \quad 1.00$ & & & & & \\
\hline Crops Production Index & 0.07 & 0.06 & -0.08 & 0.21 & -0.14 & -0.12 & -0.01 & 0.05 & 0.16 & 0.26 & -0.21 & 0.19 & -0.64 & -0.32 & -0.09 & -0.20 & -0.06 & $5 \quad-0.05$ & 1.00 & & & & \\
\hline Food Production Index & 0.09 & 0.08 & -0.13 & 0.18 & -0.12 & -0.02 & 0.03 & 0.07 & 0.21 & 0.28 & -0.17 & 0.10 & -0.55 & -0.21 & -0.08 & -0.28 & 0.06 & $6 \quad-0.14$ & 0.68 & 1.00 & & & \\
\hline $\begin{array}{l}\text { Livestock Production } \\
\text { Index }\end{array}$ & 0.04 & 0.03 & -0.03 & -0.23 & -0.23 & 0.05 & 0.10 & 0.02 & 0.20 & -0.09 & -0.13 & -0.12 & -0.25 & 0.10 & 0.08 & -0.18 & 0.17 & $7 \quad-0.11$ & 0.05 & 0.43 & 1.00 & & \\
\hline CO2 Emissions, $K T$ & 0.99 & 1.00 & 0.06 & 0.02 & 0.25 & -0.03 & -0.21 & 0.99 & 0.17 & -0.06 & -0.01 & 0.12 & 0.00 & -0.11 & 0.10 & -0.08 & 0.15 & $5 \quad 0.09$ & 0.05 & 0.07 & 0.02 & 1.00 & \\
\hline $\begin{array}{l}\text { CO2 Emissions, Metric } \\
\text { Tonnes }\end{array}$ & 0.12 & 0.13 & -0.12 & -0.12 & 0.11 & 0.28 & 0.05 & 0.13 & -0.17 & 0.52 & 0.03 & 0.31 & 0.10 & 0.27 & 0.19 & -0.22 & 0.12 & $2-0.06$ & 0.10 & 0.09 & 0.02 & 0.16 & 1.00 \\
\hline
\end{tabular}

Note: Source of data is the World Bank (2015), accessed and analyzed for the years from 1991 to 2011 ; http//data.worldbank.org/indicator

Figure A-8. Correlations among the variables for upper-middle income countries, 1991-2011. 